\title{
IVAN GAMS - TERMINOLOGIST, ENCYCLOPEDIST, BIOGRAPHER, AND MORE
}

\section{IVAN GAMS - TERMINOLOG, ENCIKLOPED, BIOGRAF IN SE KAJ}

Drago Kladnik

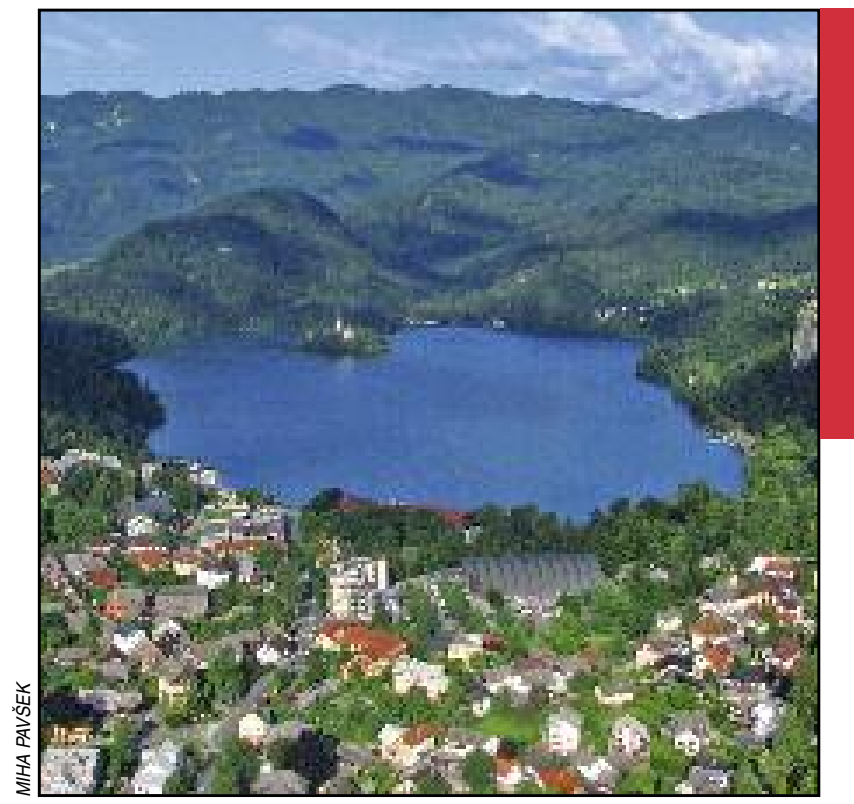

In his encyclopedic articles Ivan Gams often described lakes, such as the Bled lake on the photograph.

Pogosta tema v Gamsovih enciklopedičnih prispevkih so bila jezera, tudi Blejsko na fotografiji. 


\section{Ivan Gams - terminologist, encyclopedist, biographer, and more}

DOI: $10.3986 /$ AGS53200

UDC: 929Gams I.:91

COBISS: 1.02

ABSTRACT: In the second half of the twentieth century, Slovenian geography was characterized by gradual specialization and orientation of individuals into increasingly narrower areas of scholarly interest. Academy member Ivan Gams was no exception, focusing his research and teaching on karst studies. Throughout his work he preserved an exceptional research breadth, which is reflected in the wide variety of his contributions in all areas of physical geography; in addition, he also excelled as a regional geographer. His contributions in other areas of geography, which were by no means small, tend to pale in comparison. These reflect his constantly restless and critical research spirit, with which he helped shape Slovenia's social developments in the recent past. Outside physical geography, Gams was primarily involved in studying geographical terms and names.

KEYWORDS: Ivan Gams, terminology, geographical names, encyclopedia, biography, Slovenia

The editorial board received this article on April 14, 2013.

ADDRESS:

Drago Kladnik, Ph. D.

Anton Melik Geographical Institute

Research Centre of the Slovenian Academy of Sciences and Arts

Gosposka ulica 13, SI - 1000 Ljubljana, Slovenia

E-mail: drago.kladnik@zrc-sazu.si

\section{Contents}

1 Introduction

2 Gams' contribution to geographical terminology 218

3 Gams's contribution to geographical names 219

4 Social geography and conceptual contributions

Contributions to encyclopedias 222

Biographical contributions 224

Editing work 224

Conclusion 225

References 226 


\section{Introduction}

Ivan Gams is the most important representative of the third wave of Slovenian geographers who were the first geographers that graduated after the Second World War (Vrišer (2007). The era of the third wave of Slovenian geographers coincides with the establishment of the communist regime, whereas with Slovenia's independence in 1991, primacy was assumed by the fourth wave, which is now slowly being replaced by representatives of a fifth wave.

The period after the Second World War was characterized by gradual specialization, with individuals focusing on increasingly narrower research areas. New geographical educational and research institutions were founded, and new geographical disciplines were established that either did not exist or existed only at an amateur level, and new journals began being published. Slovenian geographers played a sort of leading role in Yugoslavia because they had the best international contacts and ensured the application of modern geographical theoretical premises and methods.

There is a difference of opinion on the achievements of the third wave of Slovenian geographers. Igor Vrišer (2007), is fairly critical, claiming that not enough was achieved with regard to the fundamental geographical question of how to scientifically explain, measure, and substantiate the connections between geographical elements and the factors in a landscape and criticizes the strong predominance of the analytical approach, which led to the fragmentation of geography and study of only certain landscape components. However, a different representative of this group, Vladimir Klemenčič (2010), is convinced that their mission was successful because a number of his contemporaries significantly helped improve the social profile of geography. In contrast to Vrišer, who regards regional geography as the apex of geographical creativity, while Klemenčič claims that the focus of landscape research is on the problem-oriented

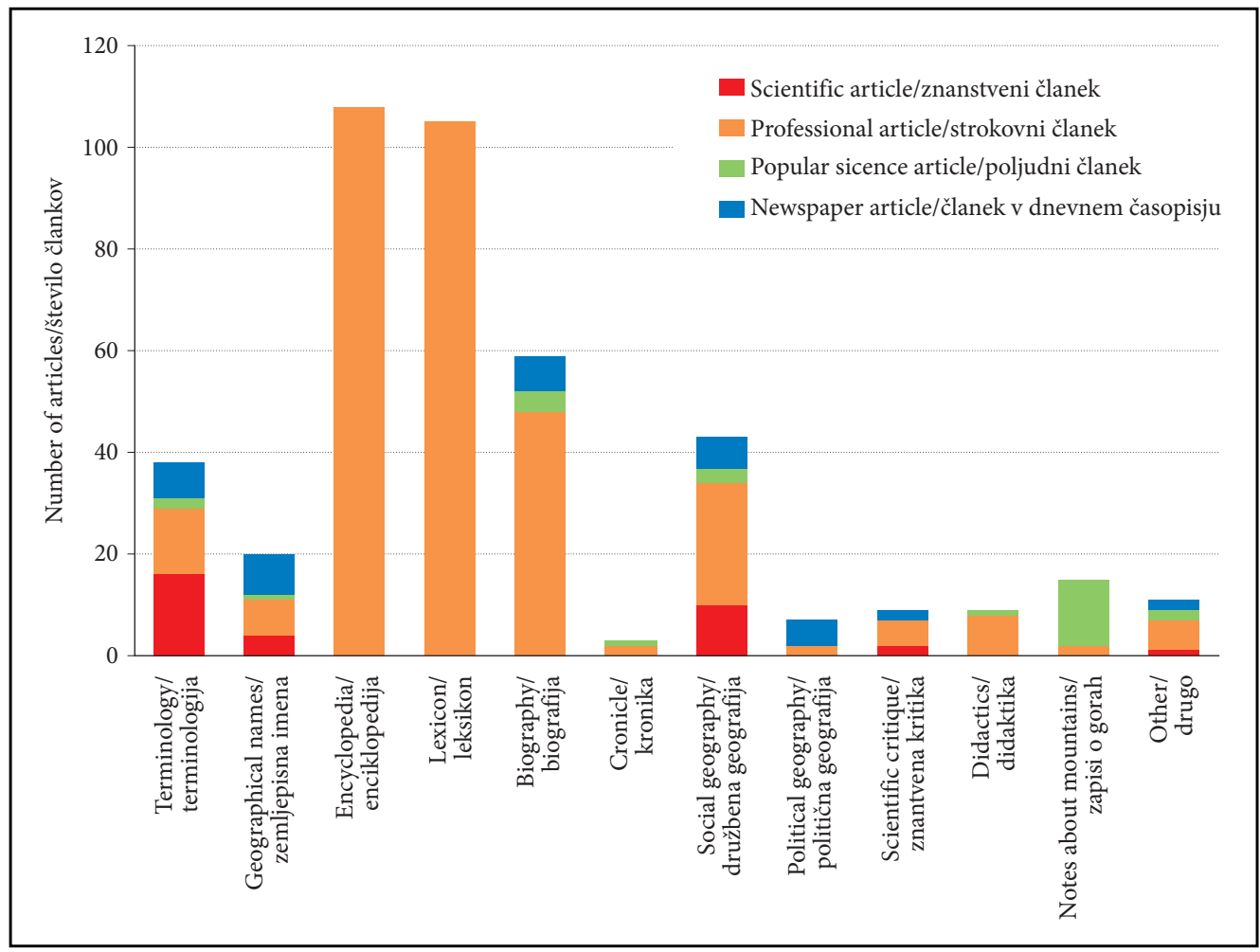

Figure 1: Works of Ivan Gams in the fields other than physical geography, karstology and regional geography according to topics and scientific level of the articles. 
approach, which generally emphasizes the regional-spatial aspect, but Klemenčič argues that a detailed analysis demands necessary research specialization.

Ivan Gams combined both concepts of geographical thought. On the one hand, he actively advocated regional geography (Perko 2013) and, on the other, he specialized in karst studies relatively quickly. Nonetheless, he preserved an incredible research and scholarly breadth, which is mirrored not only in his interest in and research on karstology (Kranjc 2013) and other branches of physical geography (Zorn and Komac 2013), but also in his interest in social geography. Gams expressed his viewpoints on research, organization of geography, and teaching geography. He also remained socially engaged throughout, excelling as a biographer and chronicler, a writer of numerous encyclopedia articles, and a guardian of good Slovenian usage, whereby he was actively involved in updating the rules for the Slovenian normative guide and the appropriate use of geographical names, especially foreign ones. He was especially fond of mountains and was also a philanthropist.

\section{Gams' contribution to geographical terminology}

Slovenian geographical terms began appearing in the first Slovenian textbooks published in the first half of the nineteenth century. A typical example of this is Cigale's Znanstvena terminologija (Technical Terminology) from 1880, which is actually a German-Slovenian terminological dictionary covering various research disciplines, including geography. The need to organize the persistently growing scope of geographical terminology was reflected in the 1925 program developed by the Ljubljana Geographical Society, in which one of the goals was the unification of Slovenian geographical terminology. However, since the researchers did not have sufficient experience to realize this goal, it has never been realized. Terminological problems were also addressed at the first conference of Yugoslav geographers, held in Belgrade in April 1927 (Kladnik, Lovrenčak and Orožen Adamič 2005). A wide variety of expressions related to surface features, bodies of water, vegetation, and paths were collected by Rudolf Badjura in his 1953 book Ljudska geografija: Terensko izrazoslovje (Folk Geography: Field Terminology). It was with a report on this very book in the journal Naši razgledi (Our Perspectives) that Ivan Gams (1953a) embarked on his terminological mission.

After the Second World War a terminological committee was established at the Institute for the Slovenian Language at the Slovenian Academy of Sciences and Arts. It collected technical terms from Slovenian technical literature. Ivan Gams participated in collecting the material and thus got to know the terminological issue in greater detail. In 1964, a 130-page list of all the terms recorded was created in addition to a list of works the terms were taken from. In conjunction with Ilešič, Gams was involved in editing and preparing the geographical headwords for Slovar slovenskega knjižnega jezika (Standard Slovenian Dictionary), which was published in five volumes between 1970 and 1991 (Kladnik, Lovrenčak and Orožen Adamič 2005).

The decision to compile a dictionary of geographical terms was readopted in 1982, and the role of its coordinator was assumed by Ivan Gams. He had already published articles on this topic s in the 1950s, and even more in the 1960s (Gams 1955c, 1961a, 1962b, 1962c, 1962d, 1963b, 1963d, 1964a, 1967d, 1968d, 1970c). Gams and his colleagues decided to publish an independent volume intended not only for the Slovenian professional community, but also elsewhere in Yugoslavia. In the framework of the Yugoslav Association of Geographical Institutions the first Yugoslav conference on karst terminology and the typology of karst features was held at the Ljubljana Faculty of Arts in October 1971 (Gams 1971a, 1973c), which was attended by twenty scholars.

Gams' terminological apex was achieved with the publication of Slovenska kraska terminologija (Slovenian Karst Terminology; Gams 1973c), for which he was the chief editor. This volume starts with an index in seven languages (Slovenian, Serbian, Croatian, Macedonian, English, German, and French), and continues with an explanation of individual terms, followed by a historical description of the development of terminology. The volume concludes with a presentation of some of the most important papers from the Ljubljana conference (Gams 1973a, 1973b; Kunaver 1973). A year after the Slovenian version of this volume, a Serbian version (Gavrilović 1974) and Croatian version (Roglić 1974) were also published. A Macedonian version was also planned, but it has never been published.

As the most agile creator of karst terminology, Gams became involved in a heated debate with geologist France Šušteršič (Gams 1974b) a year after the publication of Slovenska kraška terminologija. Šušteršič 
published a review of this book together with Dušan Novak in the journal Geografski vestnik (Geographical Gazette; Novak \& Šušteršič 1974). However, this is not where Gams' work in clarifying the meaning of karst terminology and its promotion ends; in addition to his contributions in Slovenian publications (Gams 1976a, 1979a, 1980b, 1994j, 1995b, 1996j), he also made contributions to international encyclopedias (Gams 1968b), conference proceedings (Gams 1977d, 1989a, 1991o), and journals (Gams 1993f), which testifies to his high international profile.

Very early on, Gams also began studying other types of terminology, especially related to geomorphology (Gams 1956e, 1964b) and mountaineering (Gams 1965). In addition, he also dedicated a great deal of attention to environmental terminology issues (Gams 1976b, 1977b). Following this, he returned to studying geomorphological terminology (Gams 1986g, 1989i, 1989j, 1994h) and issues connected with natural disasters (Gams 19911).

These interests are clearly connected with his work on Geografski terminološki slovar (Dictionary of Geographical Terms; Kladnik, Lovrenčak and Orožen Adamič 2005), on which he reported in one of his last contributions in addition to discussing the meaning of the terms pokrajina, krajina, and regija (all 'region'; Gams 2007). In October 1983, Gams, as the project coordinator, informed his assistants in writing about the criteria for selecting terms for the geographical terminology dictionary. Even though Gams was not involved in completing it, his conceptual contribution is more than clear: he provided entries for karst geography, geomorphology, climate geography, and general geography (Gams 2005b).

\section{Gams's contribution to geographical names}

Slovenia received its first world atlas relatively early; this was Atlant, which was published in fascicles from 1869 to 1877. It was edited by the lawyer and linguist Matej Cigale. One of Cigale's contemporaries

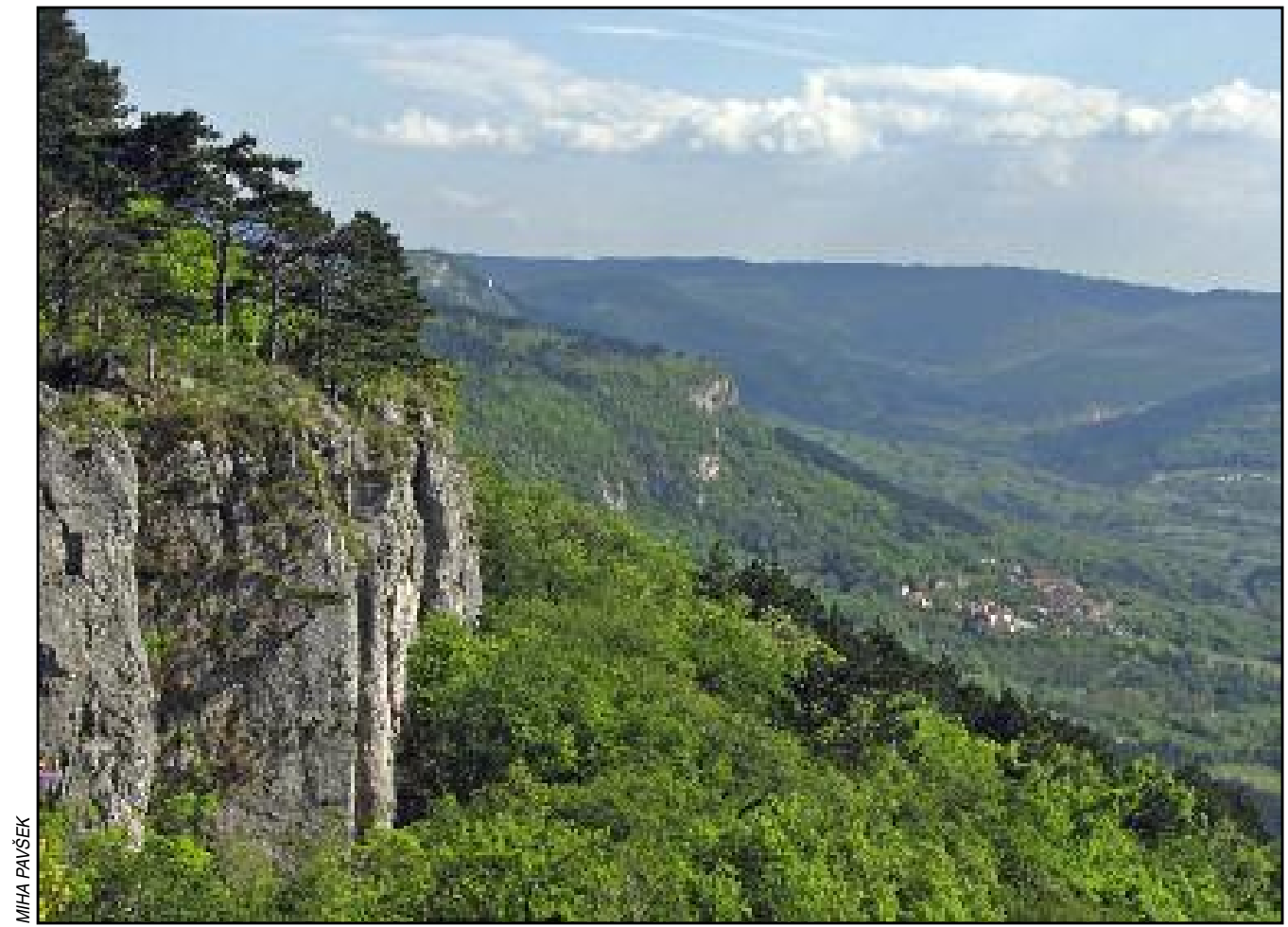

Figure 2: Ivan Gams discussed a lot about the naming of the landscape in the hinterland of the Adriatic sea. 
was the high-profile Austrian cartographer Blasius Kozenn, who was ethnically Slovenian and earned a degree in natural science. His atlases were reprinted numerous times and published in six languages. His later co-produced editions were published in even more languages, but none of them in Slovenian (Bratec Mrvar et al. 2011).

Anton Melik (1928) was the first geographer that systemically pointed out the problems with spelling foreign place names in Slovenian. Since then, geographical onomastics has been of great interest to Slovenian geographers, although the majority of them only encounter this topic and study it in parallel because they specialize in other branches of geography (Kladnik 2012).

Since the beginning of the 1970s, geographers have in principle been advocating the predominant use of native names, which to a certain degree runs against Slovenian's rich heritage in this area. In this regard, Ivan Gams was the most engaged and prominent geographer because he made continuous efforts to standardize Slovenian geographical names and simplify their capitalization. Gams' first article on geographical names, in which he addresses the non-uniform use of Slovenian exonyms, was published in the mid-1960s (Gams 1964c).

Slovenian linguists did occasionally agree with geographers' suggestions, but they generally did not accept their initiatives (cf. Kladnik 2006, 31-40). This created an impression among the public that there was a huge dispute between the two disciplines.

Disagreements were caused not only by different opinions on the appropriate use of foreign geographical names and the consequent spelling of Slovenian geographical names for places outside Slovenia, but also the use of capitalization in multiword names. The linguists did not really listen to the geographers, who, due to the international obligations tried to follow the UN recommendations on geographical names, especially the use of exonyms. Geographers did not sufficiently take into account the rich Slovenian tradition of nativizing foreign geographical names but, on the other hand, they fervently rejected exonyms from Slovenian territory in other languages, especially German and Italian.

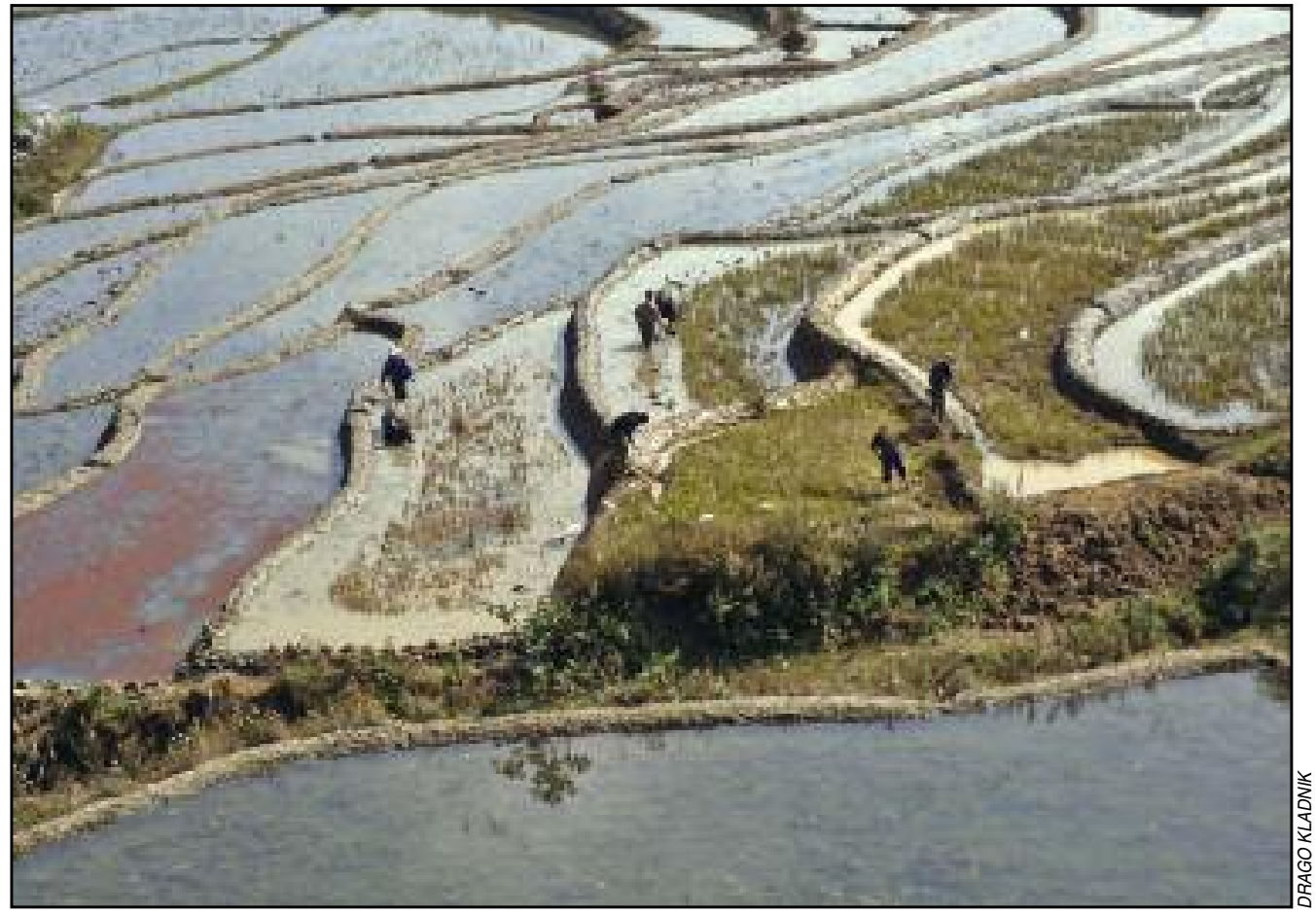

Figure 3: One of the first articles of Ivan Gams was devoted to the People's Republic of China. The photograph presents farmes on terraced rice fields in southern Yunnan. 
In 1971, the Slovenian Geographical Society decided to simplify certain rules about how to write geographical names. Therefore, under the organizational leadership of Ivan Gams, the society turned to the SAZU Institute of the Slovenian Language to co-organize a public conference on the use of geographical names (Gams 1972g, 1972h, 1972j).

Načrt pravil za novi slovenski pravopis (Draft Rules for the New Slovenian Normative Guide) was published in 1981. In connection with this, the research section of the Slovenian Geographical Society held a public consultation on the use of geographical names. At this consultation (Gams 1984e), Slovenian geographers highlighted that they opposed the establishment of the "write as you speak « principle; they opposed the proposed transliteration of Roman script into Slovenian; and in line with the UN recommendations and for completely practical communicational reasons they did not agree with the increase in the number of exonyms (Gams 1982c, 1982e, 1982f).

The geographical committee was reorganized into the Geographical Names Committee as part of the Slovenian Geographical Society which was chaired by Ivan Gams. Among other things, he wrote (Gams 1984b, 1985o) that it was geographers that had first become aware of the problem of standardizing geographical names and highlighted the need for international standardization in the conclusions of the first international geographical conference in 1871 .

As regards standardization of geographical names and toponymy and toponomastics that were addressed at a conference on standardizing geographical names in the various languages of Yugoslavia held in Sarajevo in 1984 (Gams 1984d, 1984e; Kunaver 1984) Gams wrote the following (1984d, 121): »For many participants, including linguists and geographers, the reports on international standardization efforts were completely new. " Later on, Gams published several more articles about the confusion and arbitrariness of names of regions in the media (Gams 1986d) and in journals (Gams 1987j, 1990g, 1991a).

At times, he still complained about the use of capitalization in geographical names, which he found inappropriate (Gams 1990i), and also touched upon the standardization of the Slovenian names of countries (Gams 1989h). He was especially fond of studying the appropriate use of specific names (Gams 1989b), such as the hydronym Reka (Gams 1993e, 1993g) and the oronym Snežnik (Gams 1993e). His exceptional knowledge of his native region and his refined sense of dealing with geographical names were definitely the reason why linguists (despite their disagreements) invited him to assist in the compilation of the guide Slovenska krajevna imena (Slovenian Toponyms) as the most competent informant for the correct spelling of toponyms in the municipalities of Dravograd and Slovenj Gradec (Gams 1985g, 1985k).

\section{Social geography and conceptual contributions}

This part of Gams' research is less known to the public, but it reflects the incredible breadth of his geographical thought and restless spirit, which responded energetically to current sociopolitical developments at home and abroad.

Very early on, Gams became involved in rural geography (Gams 1957a) and, in his studies of the regional differences in the transformation of agriculture in the Alps (Gams 1969a) and the value of the humid tropical zone for agriculture (Gams 1972c), he added broader regional and global dimensions to this branch of geography. He also made a vital contribution to geographical research on mountain farms in the 1980s, in which he examined the part of the Pohorje Hills around Slovenj Gradec (Gams 1982b, 1983e, 1984a); prior to this, he studied the transformation of the mountain village of Ojstrica above Dravograd in conjunction with Jakob Medved (Medved and Gams 1968). He studied land use and improvement of agricultural land in the Karst region either together with other researchers (Gams, Lovrenčak, \& Ingolič 1971; Gams \& Gabrovec 1999) or alone (Gams 1987i, 1991n); these studies formed the basis for the development of the Slovenian school of landscape ecology under his leadership (Kunaver 2005, 9).

In his early career, Gams was attracted by the development of tourism (Gams 1956a, 1959b, 1963a, $1963 \mathrm{c}, 1963 \mathrm{e}$ ), and he also tackled transport geography (Gams 1957c); in his mature years, he published several articles on the conditions and potentials of economic development (Gams 1994b, 2001a, 2002b). His two articles on the power industry also belong to this thematic category (Gams 1957b; Pagon \& Gams 1971). He also dealt with population issues, and it was actually this topic that he used to begin his magnificent body of work (Gams 1952a, 1952b, 1952c). His demographic studies on Slovenia (Gams 1961b) and abroad (Gams 1958b) were followed by reflections on the demographic threat to the Slovenian pop- 
ulation (Gams 1962a, 1972e), and articles on population density by physical geography zones (Gams 1978b) and available human living space (1982d). He also wrote about his views on deprivation and famine around the world (Gams 1988o). It is worth to emphasize his comparative analysis between population of Afghanistan and peoples of western Balkans (Gams 2001b). Based on the 1991 census data, he expanded his textbook Geografske značilnosti Slovenije (Geographical Features of Slovenia) to include current socio-geographic changes (Gams 1993b).

Gams was an excellent observer of life in foreign countries. He published articles on his views of Romania (Gams 1967a), Bulgaria (Gams 1967e), and the Soviet Union (Gams 1975b). Specially in his later career, he used a problem-oriented approach in presenting individual countries. He used this approach to present China (1956d), Tunisia (1968e), the Iberian Peninsula (Gams 1979b), Japan (Gams 1980a), Scandinavia (Gams 1980c), Malta (Gams 1986b), and Israel (Gams 1990f) to geographers and the general public.

He occasionally informed the public of his views on geography (Gams 1970d, 1977a; Gams et al. 1981), its organization (Gams 1970a, 1972f), and Slovenian geographic research (Gams 1960c, 1983f, 1985h, $1986 \mathrm{c}, 1992 \mathrm{i}$ ), in which he also discussed the borders between science and parascience together with his adherents (Zavrnik et al. 1993). He took up the idea and planned one of the main Slovenian geographical research projects, the national atlas (Gams 1966b, 1967b, 1968a), which was published in 1998 under the title Geografski atlas Slovenije (Geographical Atlas of Slovenia) after long years of efforts (Fridl et al. 1998). Very early on, Gams became aware of the role and importance of municipal atlases (Gams 1981c), but they have never been designed, especially due to a lack of funding.

Gams was continuously involved in school geography and geographical education. Already at the very beginning of this career, he touched on the issue of university and research institutions (Gams 1953b). Later on, he often reflected on, discussed, and took issue with education in primary schools (Gams 1969b; Gams \& Šircelj 1970; Gams 1993c), secondary schools (Gams 1974a, 1975a, 1993c, 2002d; Gams, Resnik Planinc, \& Saarinen 1993), and universities (Gams 1960b, 1991k).

Gams was also active as political geographer. He publically presented his viewpoints when Slovenia became independent and reorganized its administrative-political structure. He addressed both the establishment of new municipalities (Gams 1991b) and the still unsuccessful establishment of administrative regions (Gams 1998b). He displayed a continuous interest in the current political developments in Slovenia's close surroundings (Gams 1992b) as well as more distant ones (Gams 1994i, 1994k), in which he strove for a better and safer future without wars and armed conflicts. Naturally, he was also interested in ethnically Slovenian cross-border areas. He did not study this topic in great detail, but he occasionally expressed his opinion on current developments in newspapers (Gams 1972d, 1979c, 1995e).

\section{Contributions to encyclopedias}

Thanks to his extensive knowledge and geographical breadth, Gams' assistance was always welcomed in the preparation of encyclopedic works. He began his mission in this area by writing entries for the fourth volume of Krajevni leksikon Slovenije (Slovenian Gazetteer; Savnik 1980). He contributed extensive geographical descriptions of all four Carinthian municipalities, now the administrative units of Dravograd, Radlje ob Dravi, Ravne na Koroškem, and Slovenj Gradec, to this gazetteer in addition to the descriptions of thirty-four settlements in the Municipality of Slovenj Gradec. He also prepared the descriptions of the settlements in the Municipality of Slovenj Gradec for the new version of Krajevni leksikon Slovenije (Orožen Adamič, Perko and Kladnik 1995; Orožen Adamič, Perko and Kladnik 1996).

Gams wrote fifteen entries for the Enciklopedija Jugoslavije (Encyclopedia of Yugoslavia), for which six volumes up to letter $K$ were completed, but then the project was terminated with the 1991 breakup of Yugoslavia. His entries included descriptions of Slovenian Dinaric and mountainous regions (Gams 1983b, 1985b, 1985e, 1988k, 1990d, 1990e), a comprehensive description of the relief of Yugoslavia (Gams 1990c) and Slovenian Alps (1983a), an entry on the Dobratsch mountain range across the Slovenian border in Austria (Gams 1987g), descriptions of three important Slovenian lakes (Gams 1985a, 1985c, 1985d), two settlements (Gams 1987h; Gams and Šašel 1985), and one of the most important Slovenian geographers, Svetozar Ilešič (Gams 19881).

He performed outstanding work on the central Slovenian encyclopedia project, Enciklopedija Slovenije, which was published in sixteen volumes between 1987 and 2002. Gams contributed 91 entries for it either 
independently or co-authored, including some of the key ones (Gams 1988g, 1989c, 1989d, 1989e, 1989f, 1991f, 1995i, 1996e, 1996g; Gams and Petkovšek 1990; Gams et al. 1996; Gabrovec, Gams and Hrvatin 1997).

He made an important contribution to describing the Slovenian landscapes (Gams 1987b, 1987d, 1988b, 1988d, 1988h, 1988i, 1990a, 1992d, 1992e, 1995j, 1997d; Gams, Ajdič in Ferenc 1987; Gams et al. 1987; Gams and Ramovš 1990a, 1990b; Gams, Ramovš and Križnar 1990; Gams and Ževart 1993; Gams et al. 1995). He helped prepare entries on the traditional Slovenian regions (Gams et al. 1989; Gams in Štrucl 1991; Gams in Marušič 1995; Gams in Ževart 1999b) and karst and karst phenomena (Gams 1991h, 1991i, 1991;; Gams and Šušteršič 1991). He also prepared several entries describing Slovenian and Carinthian mountains (Gams 1988j, 1989g, 1991c, 1991d, 1992g, 1994c, 1994e, 1994f, 1998e, 2000; Gams, Čas and Wraber 1994; Gams and Linasi 1998; Gams, Wraber and Kunc 2000), lakes (Gams 1987c, 1987e, 1988f, 1991c, 1992f, 1994g, 1995h, 1995k, 2000; Gams et al. 1988), watercourses (Gams 1996f; Gams et al. 1993; Gams, Zupan and Povž 1994; Gams and Toman 1995), settlements (Gams 1988c, 1994d, 1995f, 1997c, 1998c, 1998d, 1999b; Gams \& Grafenauer 1992; Gams and Hozjan 1993; Gams and Linasi 1994; Gams and Stopar 1994; Gams and Ževart 1994, 1999b; Gams, Mlinšek and Oder 1999), and municipalities (Gams and Skoberne 1997a, 1997b). Gams was in charge of the entries describing Austrian Carinthia, which also has an ethnic Slovenian population (Gams 1988a, 1991e, 1992c, 1995g; Gams and Linasi 1996). As an excellent biographer, he prepared entries on the Serbian geographer Jovan Cvijić (Gams 1988e), and the Slovenian geographers Svetozar Ilešič (Gams 1990b), Andrej Kranjc (Gams 1991g), Vital Manohin (Gams 1992h), and Darko Radinja (Gams 1996d).

Ivan Gams is a great fan of mountains. This is proved by his encyclopedic contributions, and perhaps even more by over ten articles that he wrote for the journal Planinski vestnik (Mountain Gazette), in which he presented Slovenian mountains in his characteristic personal style (Gams 1953c, 1954, 1955a, 1956c, 1960a, 1962e, 1966a, 1972i, 1977e, 1987a). He also presented the Midžor Mountain on Serbian-Bulgarian

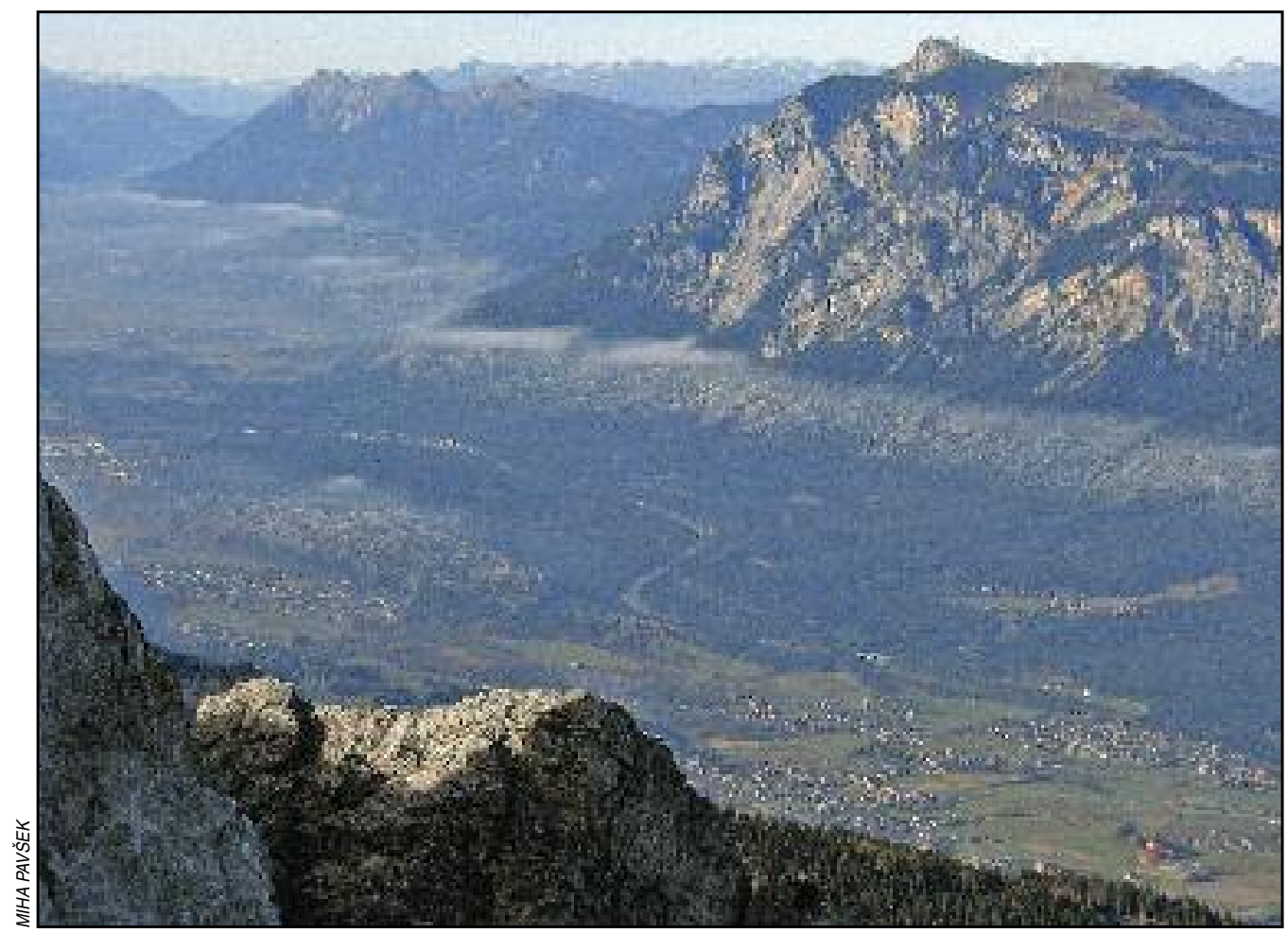

Figure 4: The Gail/Zilja valley with the Dobratsch/Dobrač mountain; Gams prepared several encyclopedic articles about Carinthia, a Slovenia-Austria cross-border region. 
border (1988q). He wrote about the modern version of the journey from Litija to Čatež in the journal Naši razgledi (Gams 1958a). He is one of the authors of the mountain guide Z Uršlje gore do Savinje (From Mount Uršlja to the Savinja River; Gams 1958c; 1964d), and his regional description of Slovenian mountains in the popular coffee-table book Slovenske gore (Slovenian Mountains; Gams 1982a) is considered especially important. His articles on mountains also include one describing Mount Everest (Gams 1955b).

As an enthusiastic photographer, he wrote an article about the photographic depiction of landscape (Gams 1959a). In his home environment, he published a brief text about his childhood memories (Gams 1996i), and expressed his philanthropic side in a text describing his relationship to other cultures (Gams 1995c).

\section{Biographical contributions}

Even leaving aside his numerous book reviews, which he regularly published especially in the journal Geografski vestnik, Ivan Gams was also one of Slovenia's most productive geographical biographers. He wrote more contributions of this type in the second half of his career, when he had already obtained the status of a highly respected and objective scholar, whose opinion had great weight. Therefore it is not surprising that he was "in charge " of monitoring and evaluating the scholarly creativity and teaching performance of the most respected Slovenian geographers. He dedicated the majority (i.e., eleven) of his articles to academy member Svetozar Ilešič (Gams 1967c, 1977c, 1985f, 1985i, 1985l, 1985m, 1985n, 1986a, 1996c, 1999a, 2008). He only reported on another important Slovenian geographer, Anton Melik, after his death (Gams 1991m, 2005a, 2005c), as on natural scientist Ferdinand Seidl (Gams 1992a), the precursor of Slovenian scientific regional geography. He diligently followed all the milestone birthdays and also the later death of the prominent representative of the interwar group of Slovenian geographers, Valter Bohinc (Gams 1968c, 1978a, 1984f, 1984g), and he also presented the work and achievements of social geographer and academician Igor Vrišer (Gams 1990h, 1993a). As an academy member, he presented the youngest Slovenian academy member in geography, the karst specialist Andrej Kranjc (Gams 1995d, 1996a, 2002a).

Gams also wrote about the achievements of the Slovenian geographers France Planina (Gams 1971b), Vilko Finžgar (1972a), Roman Savnik (Gams 1972b), Tone Oblak (Gams 1974c), Marjan Žagar (Gams 1980d, 1981b, 1984c), Danilo Furlan (Gams 1983c, 1983d), Cene Malovrh (Gams 1985j), Drago Meze (Gams 1986e, 1996b, 1996h), Darko Radinja (Gams 1987f, 1987l, 1997a, 1997b), Milan Šifrer (Gams 1988n), Jurij Kunaver (Gams 1993d, 2003), Peter Habič (Gams 1994a), Slava Rakovec (Gams 2002e) when they celebrated milestone birthdays or when they died and also autobiographical articles about himself and his work (Gams 1988m, 1995a). Gams informed the Slovenian professional community of the deaths of the prominent Yugoslav physical geographers Josip Roglić (Gams 1987k, 1987m, 1987n) and Milislav Lutovac (Gams 1988p), as well as the death of eminent physical geographers from other countries that specialized in karst studies, such as Jean Corbel (Gams 1970b) and Herbert Lehmann (Gams 1971c), and the geographer and geologist Julius Fink (Gams 1981a). He wrote an article about the French geomorphologist Jean Corbel (Gams and Kranjc 2004) who was appointed an honorary member of the Slovenian Academy of Sciences and Arts.

In the journal Geografski vestnik, on whose seventieth anniversary he reported in the editorial for its 67th issue (Gams 1995l), he also bid farewell to his fellow academy member, the geologist Ivan Rakovec (Gams 1986f), and his colleague Dušan Novak (Gams 1998a), who specialized in caves; in the Czech speleological journal Speleo, he wrote about one of the pioneers of systematically studying and inventorying the Slovenian karst underground and one of those that contributed to founding the Society for Cave Exploration, which was established in Ljubljana in 1910: Viljem Putick (Wilhelm Puttik), a native of Moravia (Gams 2002c). Gams had already written an article about Putick in the central Slovenian natural science journal Proteus in the 1950s (1956b).

\section{Editing work}

Because Gams wrote a lot, he did not have much time to work as an editor; he probably was not as good at editing, and also was not as fond of it as of writing. He only rarely edited works by himself; for example, the publications Vodnik kongresne ekskurzije po dinarskem krasu (Guide to the Dinaric Karst Region 
for the Conference Excursion, 1965), Karst Processes and Relevant Landforms (1976), and Naravne nesreče $v$ Sloveniji kot naša ogroženost (Natural Disasters in Slovenia as a Threat, 1983). He more often served as a co-editor, such as for the volumes Dolenjska zemlja in ljudje (Lower Carniola and Its People, 1962), Zbornik VI. kongresa geografov FLRJ v LR Sloveniji (Proceedings of the Sixth Conference of Geographers of the Federal People's Republic of Yugoslavia in the People's Republic of Slovenia, 1962), Jamarski priročnik (Speleology Manual, 1964), the English publications Karst and Man and Man's Impact in Dinaric Karst (1987), and the important book for geographical experts Geografija Slovenije (Geography of Slovenia, 1998). From 1983 to 1994, he was the co-editor of the journal Geografski zbornik, and was a member of the editorial board of the main Slovenian geographical journal Geografski vestnik for thirty-nine years.

Ivan Gams was member of numerous Slovenian and international research bodies (Kunaver 2005). He was the chair of the Slovenian Society for Cave Exploration, the chair of the Slovenian Geographical Society between 1968 and 1972, and for a short time also the chair of its Ljubljana branch.

Between 1983 and 1995, he chaired the research council of the ZRC SAZU Anton Melik Geographical Institute. He also served one term as the head of the Department of Geography at the University of Ljubljana's Faculty of Arts.

In 1978, he was elected an honorary member of the Slovenian Academy of Sciences and Arts, and has been a full member since 1985. In 1993, the European Academy of Sciences and Arts, founded in Salzburg, appointed him a full member. In December 1993, he was appointed a distinguished professor at the proposal of the Faculty of Arts' Department of Geography. He is also an honorary citizen of the Municipality of Slovenj Gradec (Kunaver 2005).

\section{Conclusion}

As already noted by Kunaver (2005), exceptional figures are one of the greatest added values of the national discipline because they serve as a precious model at home, and also make an impact abroad. In Slovenian

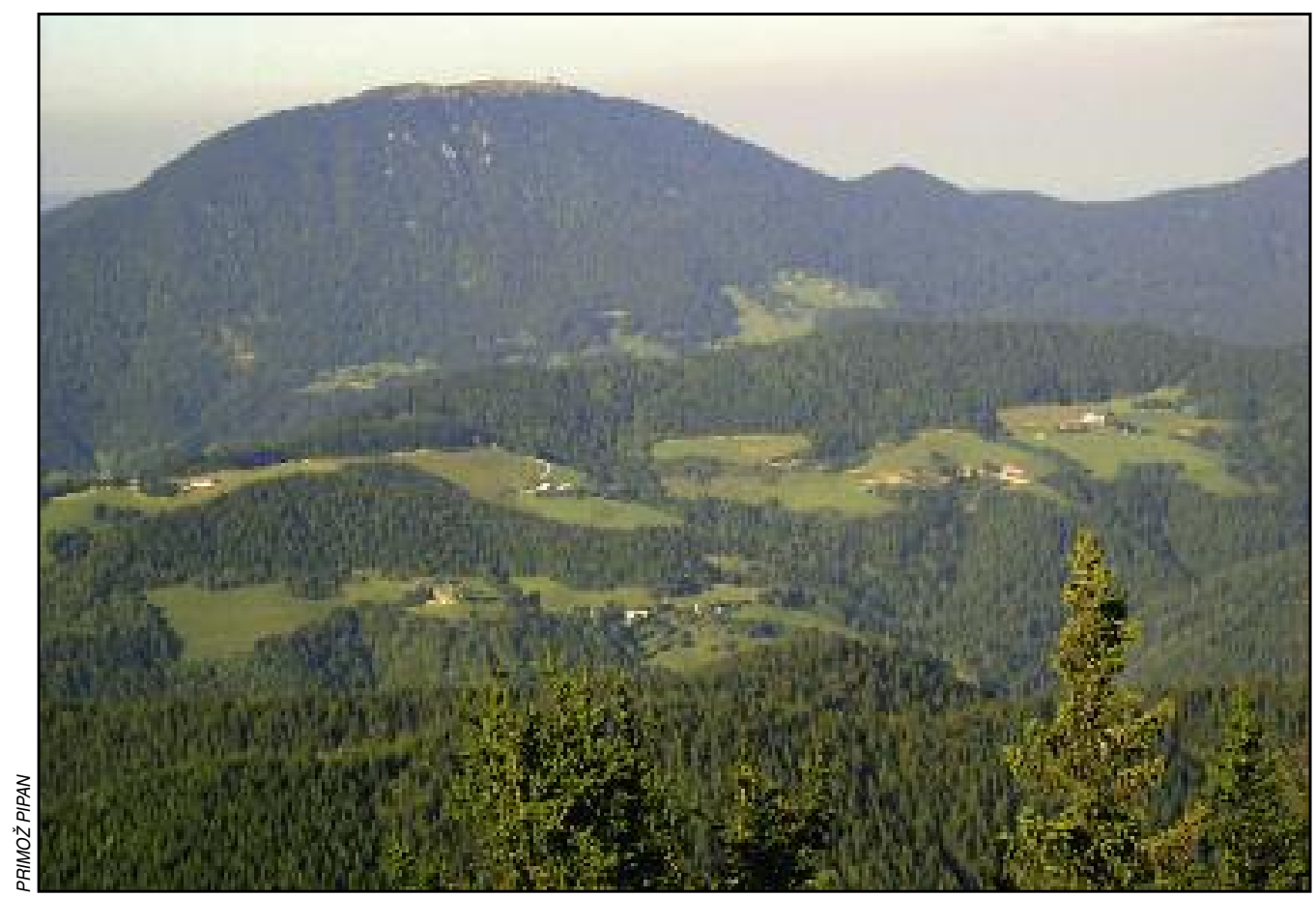

Slika 5: Med vsemi vzpetinami je bila Gamsu morda najbližja plečata Uršlja gora ali Plešivec. 
geography, such a place is held by Ivan Gams, which is proved not only by his extensive lists of published works, but also his broad view of and interest in a wide variety of issues in geography and current social developments. His most striking characteristics as a scholar, researcher, and teacher include nonconformity, tactfulness, originality, diversity of geographical thought, paving new research paths and methods, and unveiling issues that no one in Slovenia had generally tackled before him. This is complemented by his Carinthian stubbornness, relentlessness, and unbending nature, which helped him tread his own path without relying on the ruling circles and exploiting the advantage of "appropriate « sociopolitical affiliation.

\section{References}

Atlant, 16 zemljevidov. Matica Slovenska. Ljubljana, 1869-1877.

Bratec Mrvar, R., Birsak, L., Fridl, J., Kladnik, D., Kunaver, J. 2011: Kocenov srednješolski atlas kot didaktična prelomnica. Geografija Slovenije 22. Ljubljana.

Faninger, E., Gams, I., Marinček, L., Martinčič, A., Mlinšek, D., Ževart, M. 1995: Pohorje. Enciklopedija Slovenije, 9. zvezek. Ljubljana.

Fridl, J., Kladnik, D., Orožen Adamič, M., Perko, D. (uredniki) 1998: Geografski atlas Slovenije. Ljubljana. Gabrovec, M., Hrvatin, M., Gams, I. 1997: Slovenija. Relief. Enciklopedija Slovenije, 11. zvezek. Ljubljana. Gams, I. 1952a: Človek na zemlji Slovenjgraške kotline. Geografski zbornik 1. Ljubljana.

Gams, I. 1952b: Kmetijske panoge Slovenije v luči gibanja prebivalstva: 1931-1948. Naši razgledi 1-11. Ljubljana.

Gams, I. 1952c: Še o gibanju prebivalstva Slovenije v letih 1931-1948. Geografski vestnik 24. Ljubljana.

Gams, I. 1953a: K problemu slovenskega geografskega izrazoslovja: ob Badjurovi Ljudski geografiji. Naši razgledi 2-21. Ljubljana.

Gams, I. 1953b: O vprašanju visokih šol in znanstvenih institucij. Naši razgledi 2-11. Ljubljana.

Gams, I. 1953c: Še nekaj o severni triglavski steni. Planinski vestnik 9-5. Ljubljana.

Gams, I. 1954: Razgledi s Storžiča. Planinski vestnik 10-1. Ljubljana.

Gams, I. 1955a: Goričko - Prekmurske Alpe. Planinski vestnik 11-8. Ljubljana.

Gams, I. 1955b: Kako visok je Everest? Geografski obzornik 2-3. Ljubljana.

Gams, I. 1955c: Kraška piraterija. Proteus 17-6. Ljubljana.

Gams, I. 1956a: Dva Stara trga in Kolpa med njima. Turistični vestnik 4-7. Ljubljana.

Gams, I. 1956b: Jamoslovec Viljem Putick. Proteus 19-4/5. Ljubljana.

Gams, I. 1956c: Med Planico, Bavšico in Trento. Planinski vestnik 12-1. Ljubljana.

Gams, I. 1956d: Prirodna, nacionalna in upravno politična sestava Kitajske. Geografski obzornik 3-3. Ljubljana.

Gams, I. 1956e: Zemljepisno izrazje: usad - podor - kameniti plaz - soliflukcija - kraški udor in še kaj. Geografski obzornik 3-1. Ljubljana.

Gams, I. 1957a: Agrarno-geografska analiza Ropoče: po upadu goričkega vinogradništva. Svet ob Muri 2-2. Murska Sobota.

Gams, I. 1957b: Evropska energetska bilanca in jedrska energija. Geografski obzornik 4-3. Ljubljana.

Gams, I. 1957c: Sotelska železnica. Geografski obzornik 4-2. Ljubljana.

Gams, I. 1958a: Potovanje iz Litije do Čateža: sto let za Levstikom. Naši razgledi 7-24. Ljubljana.

Gams, I. 1958b: Rast in socialna preobrazba prebivalstva v Sovjetski zvezi. Geografski obzornik 5-1. Ljubljana.

Gams, I. 1958c: S Plešivca do Savinje. Po slovenskih gorah. Ljubljana.

Gams, I. 1959a: O fotografskem upodabljanju pokrajine. Geografski obzornik 6-4. Ljubljana.

Gams, I. 1959b: Pohorsko Podravje in motorizirani turizem. Turistični vestnik 7-12. Ljubljana.

Gams, I. 1960a: Mir in nemir v gorah. Planinski vestnik 16-4. Ljubljana.

Gams, I. 1960b: O geografiji: v reformiranem univerzitetnem študiju in v praksi. Naši razgledi 9-10. Ljubljana.

Gams, I. 1960c: Vrednotenje geografsko raziskovalne dejavnosti. Naši razgledi 9-10. Ljubljana.

Gams, I. 1961a: Kras - zakrasevanje - ukrasevanje. Geografski obzornik 8-1. Ljubljana.

Gams, I. 1961b: Porast prebivalstva LR Slovenije v letih 1953-1961 po občinah: (prvi rezultati popisa). Geografski obzornik 8-2. Ljubljana.

Gams, I. 1962a: Ali Slovenci izumiramo. Delo, 19.2.1972. Ljubljana.

Gams, I. 1962b: Ali so na Kubi pečine ali jame? Delo, 10. 11. 1962. Ljubljana. 
Gams, I. 1962c: Kaj je prav: kras ali Kras? Delo, 6.11.1962. Ljubljana.

Gams, I. 1962d: Še besedo, dve o kraški terminologiji. Delo, 26. 5. 1962. Ljubljana.

Gams, I. 1962e: Velo polje, tako kot je in naj bi bilo. Planinski vestnik 62. Ljubljana.

Gams, I. 1963a: Jamski turizem, razvoj v polpretekli dobi in sedanja problematika. Turistični vestnik 11-11. Ljubljana.

Gams, I. 1963b: Kraška terminologija. Geografski vestnik 34. Ljubljana.

Gams, I. 1963c: Kraški turizem v polpretekli dobi in sedanja problematika. Turistični vestnik 11-11. Ljubljana,. Gams, I. 1963d: Terminologija večjih kraških oblik. Geografski vestnik 34. Ljubljana.

Gams, I. 1963e: Velike možnosti za razmah turizma na Krasu: načrti o trajnem Cerkniškem jezeru in povezavi Postojnske jame s Planinsko. Delo, 14. 5. 1963. Ljubljana.

Gams, I. 1964a: Kako imenujemo površinske kraške oblike. Gozdni gospodar 5-2. Postojna.

Gams, I. 1964b: Klasifikacija vršajev. Geografski obzornik 11-3. Ljubljana.

Gams, I. 1964c: Krakov, Wroclav, Varšava. Naši razgledi 13-2. Ljubljana.

Gams, I. 1964d: Z Uršlje gore do Savinje. Vodnik po slovenskih gorah. Ljubljana.

Gams, I. 1965: Še o gorniških izrazih. Planinski vestnik 65-8. Ljubljana.

Gams, I. 1966a: Ljudje, čas in gora: napisano za 70-letnico Planinskega vestnika. Planinski vestnik 66-7. Ljubljana.

Gams, I. 1966b: O Atlasu Slovenije. Naši razgledi 15-13. Ljubljana.

Gams, I. 1967a: Ekskurzijske beležke o geografiji Romunije. Geografski obzornik 14-3. Ljubljana.

Gams, I. 1967b: Načrtovanje jugoslovanskega in slovenskega nacionalnega atlasa. Geografski vestnik 39. Ljubljana.

Gams, I. 1967c: Svetozar Ilešič: šestdesetletnik. Geografski vestnik 39. Ljubljana.

Gams, I. 1967d: Termokras. Geografski obzornik 14-1. Ljubljana.

Gams, I. 1967e: Turistični zapiski iz Bolgarije. Turistični vestnik 15-1. Ljubljana.

Gams, I. 1968a: Atlas Slovenije - da ali ne? Naši razgledi 17-10. Ljubljana.

Gams, I. 1968b: Blind valley. The encyclopedia of geomorphology. New York, Amsterdam, London.

Gams, I. 1968c: Prof. dr. Valter Bohinec - sedemdesetletnik. Geografski vestnik 40. Ljubljana.

Gams, I. 1968d: Slovenska terminologija tipov tropskega krasa. Geografski obzornik 15-3/4. Ljubljana.

Gams, I. 1968e: Tunizija v dvanajstem letu dekolonizacije. Geografski obzornik 15-1/2. Ljubljana.

Gams, I. 1969a: O regionalnih razlikah pri preobrazbi kmetijstva v Alpah. Geografski obzornik 16-1. Ljubljana.

Gams, I. 1969b: Strokovna kvalifikacija učiteljev geografije na osnovnih šolah Slovenije. Geografski obzornik 16-2. Ljubljana.

Gams, I. 1970a: Aktualne naloge v slovenski geografiji in v Geografskem društvu Slovenije. Geografski obzornik 17-3/4. Ljubljana.

Gams, I. 1970b: Ob smrti Jeana Corbela. Geografski vestnik 42. Ljubljana.

Gams, I. 1970c: Terminologija, znanost in sodni dan. Delo, 24.12. 1970. Ljubljana.

Gams, I. 1970d: Univerzalna ali nacionalna geografija. Geografski vestnik 42. Ljubljana.

Gams, I. 1971a: Na Krasu je kras: na rob simpoziju o kraški terminologiji. Delo, 24. 10. 1971. Ljubljana.

Gams, I. 1971b: Ob sedemdesetletnici rojstva Franceta Planine. Geografski obzornik 18-3/4. Ljubljana.

Gams, I. 1971c: Umrl je prof. dr. Herbert Lehmann. Geografski vestnik 43. Ljubljana.

Gams, I. 1972a: Govor ob odprtem grobu Vilka Finžgarja. Geografski obzornik 19-2. Ljubljana.

Gams, I. 1972b: Na rob sedemdesetletnice dr. Romana Savnika. Geografski obzornik 19-1. Ljubljana.

Gams, I. 1972c: O vrednosti vlažnotropskega pasu za kmetijstvo. Geografski obzornik 19-4. Ljubljana.

Gams, I. 1972d: Pri treh županih na Goriškem in Tržaškem. Naši razgledi 21-13. Ljubljana.

Gams, I. 1972e: Rodnost, rodoljubnost in standard. Prostor in čas: revija za kulturna in družbena vprašanja 4-1/2. Ljubljana.

Gams, I. 1972f: Slavnostna proslava petdesetletnice GDS. Geografski obzornik 19-2. Ljubljana.

Gams, I. 1972g: Za poenostavitev pravopisnih pravil: poročilo s posvetov o pisanju zemljepisnih imen I. Naši razgledi 21-22, 24.11.1972. Ljubljana.

Gams, I. 1972h: Za poenostavitev pravopisnih pravil: poročilo s posvetov o pisanju zemljepisnih imen II. Naši razgledi 21-23, 8. 12. 1972. Ljubljana.

Gams, I. 1972i: Zasenčeni razgledi. Planinski vestnik 72-3. Ljubljana.

Gams, I. 1972j: Zemljepisna imena na rešetu. Delo, 18. 1. 1972. Ljubljana. 
Gams, I. 1973a: Razvoj slovenskih besed kras in dolina v mednarodna termina do konca 19. stoletja. Slovenska kraška terminologija. Ljubljana.

Gams, I. 1973b: Terminologija tipov kraških polj. Slovenska kraška terminologija. Ljubljana.

Gams, I. (urednik) 1973c: Slovenska kraška terminologija. Ljubljana.

Gams, I. 1974a: O konceptu geografije za 2. in 3. razred gimnazije. Geografski obzornik 21-2/3. Ljubljana. Gams, I. 1974b: Pripombe na Šušteršičevo oceno kraške terminologije. Geografski vestnik 46. Ljubljana. Gams, I. 1974c: V spomin profesorja Toneta Oblaka. Geografski obzornik 21-1. Ljubljana.

Gams, I. 1975a: Geografija v reformirani šoli. Prosvetni delavec 26-8. Ljubljana.

Gams, I. 1975b: Geografske beležke iz Sovjetske zveze. Geografski obzornik 22-1/2. Ljubljana.

Gams, I. 1976a: Karst processes and relevant landforms (Kraški procesi in ustrezne površinske oblike). Geografski obzornik 23-3/4. Ljubljana.

Gams, I. 1976b: Smog ali smod? Delo, Sobotna priloga, 31. 1. 1976. Ljubljana.

Gams, I. 1977a: Meje geografije v sistemu znanosti in v šoli. Geografski obzornik 24-3/4. Ljubljana.

Gams, I. 1977b: Okolje - človekovo okolje - geografsko okolje - geografija. Geografski vestnik 49. Ljubljana. Gams, I. 1977c: Svetozar Ilešič, sedemdesetletnik. Delo, 15. 6. 1977. Ljubljana.

Gams, I. 1977d: Towards the terminology of the polje. Proceedings of the 70th International Speleological Congress. Sheffield.

Gams, I. 1977e: Uršlja, gora mojih spoznanj. Planinski vestnik 77-10. Ljubljana.

Gams, I. 1978a: Častni član GDS prof. dr. Valter Bohinec je dopolnil osemdeset let. Geografski vestnik 50. Ljubljana.

Gams, I. 1978b: Prebivalstvena gostota po naravnogeografskih pasovih Zemlje: (primer naravnogeografske pogojenosti družbenega pojava). Geografski obzornik 25-3/4. Ljubljana.

Gams, I. 1979a: Jamarstvo: jamoslovje ali jamarstvo + jamoslovje? Naše jame 20. Ljubljana.

Gams, I. 1979b: Nekatere geografske stalnice Iberskega polotoka. Geografski obzornik 26-1/2. Ljubljana.

Gams, I. 1979c: Ob naši zahodni etnični meji: »če hočemo tem ljudem pomagati, moramo izhajati iz njihove in ne naše psihe«. Naši razgledi 28-1. Ljubljana.

Gams, I. 1980a: Kmetov je le še desetina prebivalstva: Japonska v očeh udeleženca mednarodnega geografskega kongresa. Delo, 27.9. 1980. Ljubljana.

Gams, I. 1980b: Sigove tvorbe - kapniki - Kras - kras. Geografski vestnik 52. Ljubljana.

Gams, I. 1980c: Skandinavija ima svoj nerazviti sever. Geografski obzornik 27-3/4. Ljubljana.

Gams, I. 1980d: Univ. prof. dr. Marjan Žagar - šestdesetletnik. Geografski vestnik 53. Ljubljana.

Gams, I. 1981a: † Prof. dr. Julius Fink. Geografski vestnik 53. Ljubljana.

Gams, I. 1981b: Ob grobu prof. dr. Marjana Žagarja. Geografski obzornik 28-1/2. Ljubljana.

Gams, I. 1981c: Občinski atlasi. Geografski vestnik 53. Ljubljana.

Gams, I. 1982a: Gore. Slovenske gore. Ljubljana.

Gams, I. 1982b: Hribovske kmetije slovenjgraškega Pohorja: stanje in dejavniki razvoja. Geografske značilnosti preobrazbe slovenskega podeželja. Ljubljana.

Gams, I. 1982c: Jezik slovenski tone? Delo, Sobotna priloga, 16. 1.1982. Ljubljana.

Gams, I. 1982d: Razpoložljivi življenjski prostor. Bomo preživeli? Celje.

Gams, I. 1982e: Zemljepisna naselbinska imena v Načrtu pravil za novi Slovenski pravopis (predlog za spremembe). Spoznanja in pripombe javne razprave o načrtu pravil za novi Slovenski pravopis. Ljubljana.

Gams, I. 1982f: Zemljepisna naselbinska imena v Načrtu pravil za novi Slovenski pravopis (predlog za spremembe). Separat. Ljubljana.

Gams, I. 1983a: Alpe, Slovenske. Enciklopedija Jugoslavije, 1. knjiga. Zagreb.

Gams, I. 1983b: Bela krajina. Enciklopedija Jugoslavije, 1. knjiga. Zagreb.

Gams, I. 1983c: Danilo Furlan sedemdesetletnik. Delo, 22.3. 1983. Ljubljana.

Gams, I. 1983d: Ob sedemdesetletnici dr. Danila Furlana. Geografski vestnik 55. Ljubljana.

Gams, I. 1983e: Prostovoljci na hribovskih kmetijah. Delo, 3.9.1983. Ljubljana.

Gams, I. 1983f: Stanje in perspektive slovenske raziskovalne geografije. Geografski vestnik 55. Ljubljana.

Gams, I. 1984a: Hribovske kmetije slovenjgraškega Pohorja. Geografski zbornik 23. Ljubljana.

Gams, I. 1984b: Laibachi, Spalati, Marburgi ... počasi izginjajo. Delo, Sobotna priloga, 17.3. 1984. Ljubljana.

Gams, I. 1984c: Marjan Žagar (1920-1980). Med Bočem in Bohorjem. Šentjur pri Celju, Šmarje pri Jelšah, Rogaška Slatina. 
Gams, I. 1984d: Posvet o vprašanjih standardizacije geografskih imen v jezikih narodov in narodnosti SFRJ, 8.-9. marec 1984 v Sarajevu. Geografski vestnik 56. Ljubljana.

Gams, I. 1984e: Prizadevanje Geografskega društva Slovenije za standardizacijo slovenskih lastnih geografskih imen. Zbornik radova savjetovanja o pitanjima standardizacije geografskih naziva u jezicima naroda i narodnosti SFRJ. Geografsko društvo Bosne i Hercegovine. Sarajevo.

Gams, I. 1984f: V spomin prof. dr. Valterja Bohinca. Geografski vestnik 56. Ljubljana.

Gams, I. 1984g: Valter Bohinec: in memoriam. Naši razgledi 31-11. Ljubljana.

Gams, I. 1985a: Blejsko jezero. Enciklopedija Jugoslavije, 2. knjiga. Zagreb.

Gams, I. 1985b: Bloke (Bloška planota). Enciklopedija Jugoslavije, 2. knjiga. Zagreb.

Gams, I. 1985c: Bohinjsko jezero. Enciklopedija Jugoslavije, 2. knjiga. Zagreb.

Gams, I. 1985d: Cerkniško jezero. Enciklopedija Jugoslavije, 2. knjiga. Zagreb.

Gams, I. 1985e: Cerkniško polje. Enciklopedija Jugoslavije, 2. knjiga. Zagreb.

Gams, I. 1985f: Dr. Svetozar Ilešič. Delo, 6.2.1985. Ljubljana.

Gams, I. 1985g: Dravograd (informator za občino). Slovenska krajevna imena. Ljubljana.

Gams, I. 1985h: Problemi sodobnega raziskovanja gorskih sistemov. Geografski vestnik 57. Ljubljana.

Gams, I. 1985i: Profesorju Svetozarju Ilešiču v slovo. Vestnik 14-7. Ljubljana.

Gams, I. 1985j: Sedemdesetletnica univ. prof. dr. Vincenca Malovrha. Geografski vestnik 57. Ljubljana.

Gams, I. 1985k: Slovenj Gradec (informator za občino). Slovenska krajevna imena. Ljubljana.

Gams, I. 1985l: Svetozar Ilešič (1907-1985). Letopis Slovenske akademije znanosti in umetnosti, knjiga 36. Ljubljana.

Gams, I. 1985m: Svetozar Ilešič: 1907-1985. Geografski zbornik 24. Ljubljana.

Gams, I. 1985n: Svetozar Ilešič: in memoriam. Naši razgledi 34-5. Ljubljana.

Gams, I. 1985o: V Lozani (Lausanni) Lausannu? Delo, Sobotna priloga, 18. 5. 1985. Ljubljana.

Gams, I. 1986a: Akademik prof dr. Svetozar Ilešič. Acta carsologica 14/15. Ljubljana.

Gams, I. 1986b: Malta. Obzornik 3. Ljubljana.

Gams, I. 1986c: Multidisciplinarni pomen zbiranja ljudskega znanja o lokalnem okolju. O razmerju med geografijo in etnologijo. Ljubljana.

Gams, I. 1986d: O zmedi in samovolji naših krajinskih imen. Delo, Sobotna priloga, 18. 10. 1986. Ljubljana.

Gams, I. 1986e: Šestdesetletnica Draga Mezeta. Geografski vestnik 58. Ljubljana.

Gams, I. 1986f: V spomin akademiku Ivanu Rakovcu (1899-1985). Geografski vestnik 58. Ljubljana.

Gams, I. 1986g: Za kvantitativno razmejitev med pojmi gričevje, hribovje in gorovje. Geografski vestnik 58. Ljubljana.

Gams, I. 1987a: Ali je Slovenija gorata dežela? Planinski vestnik 87-1. Ljubljana.

Gams, I. 1987b: Babno polje. Enciklopedija Slovenije, 1. zvezek. Ljubljana.

Gams, I. 1987c: Baško jezero. Enciklopedija Slovenije, 1. zvezek. Ljubljana.

Gams, I. 1987d: Bela krajina. Enciklopedija Slovenije, 1. zvezek. Ljubljana.

Gams, I. 1987e: Belo jezero. Enciklopedija Slovenije, 1. zvezek. Ljubljana.

Gams, I. 1987f: Darko Radinja - šestdesetletnik. Delo, 15. 1. 1987. Ljubljana.

Gams, I. 1987g: Dobrač (nem. Villacher Alp). Enciklopedija Jugoslavije, 3. knjiga. Zagreb.

Gams, I. 1987h: Gozd Martuljek. Enciklopedija Jugoslavije, 4. knjiga. Zagreb.

Gams, I. 1987i: Kraške agromelioracije: nastajanje, oblike in pomen za sedanjo rabo tal. Pokrajinski učinki človekovih dejavnosti na življenjsko okolje. Bled.

Gams, I. 1987j: O zmedi in samovolji pri uporabi naših pokrajinskih imen. Geografski vestnik 59. Ljubljana. Gams, I. 1987k: Ob grobu akademika prof. dr. Josipa Roglića 22.10. 1987. Geografski obzornik 34-3. Ljubljana. Gams, I. 1987l: Prof. dr. Darko Radinja - šestdesetletnik. Geografski vestnik 59. Ljubljana.

Gams, I. 1987m: Umrl je akademik Josip Roglić. Naše jame 29. Ljubljana.

Gams, I. 1987n: V spomin akademika Josipa Roglića: 1906-1987. Geografski vestnik 59. Ljubljana.

Gams, I. 1988a: Celovška kotlina. Enciklopedija Slovenije, 2. zvezek. Ljubljana.

Gams, I. 1988b: Cerkljansko. Enciklopedija Slovenije, 2. zvezek. Ljubljana.

Gams, I. 1988c: Cerknica. Enciklopedija Slovenije, 2. zvezek. Ljubljana.

Gams, I. 1988d: Cerkniško polje. Enciklopedija Slovenije, 2. zvezek. Ljubljana.

Gams, I. 1988e: Cvijić, Jovan. Enciklopedija Slovenije, 2. zvezek. Ljubljana.

Gams, I. 1988f: Črno jezero. Enciklopedija Slovenije, 2. zvezek. Ljubljana.

Gams, I. 1988g: Denudacija. Enciklopedija Slovenije, 2. zvezek. Ljubljana. 
Gams, I. 1988h: Dinarski kras. Enciklopedija Slovenije, 2. zvezek. Ljubljana.

Gams, I. 1988i: Dinarsko gorstvo. Enciklopedija Slovenije, 2. zvezek. Ljubljana.

Gams, I. 1988j: Dobrač. Enciklopedija Slovenije, 2. zvezek. Ljubljana.

Gams, I. 1988k: Idrijsko hribovje (Idrijska Brda). Enciklopedija Jugoslavije, 5. knjiga. Zagreb.

Gams, I. 19881: Ilešič, Svetozar. Enciklopedija Jugoslavije, 5. knjiga. Zagreb.

Gams, I. 1988m: Ivan Gams. Slovenska akademija znanosti in umetnosti: biografski zbornik. Ljubljana.

Gams, I. 1988n: Ob šestdesetletnici priznanega slovenskega geomorfologa dr. Milana Šifrerja. Loški razgledi 34. Škofja Loka.

Gams, I. 1988o: Razvoj iz pomanjkanja in geografija lakote. Geografski obzornik 35-3. Ljubljana.

Gams, I. 1988p: Umrl je akademik Milislav V. Lutovac: (1901-1988). Geografski vestnik 60. Ljubljana.

Gams, I. 1988q: Zaraščene poti po florističnem parku: na Midžoru $(2169 \mathrm{~m})$ in po krajih pod Staro planino. Planinski vestnik 89-11. Ljubljana.

Gams, I. 1989a: A new definition of karst. Resource management in limestone landscapes: international perspectives: proceedings of the International geographical union, Study group Man's impact on karst. Sydney.

Gams, I. 1989b: Dogovorimo se za ime predora. Delo, 3. 5. 1989. Ljubljana.

Gams, I. 1989c: Fizična geografija. Enciklopedija Slovenije, 3. zvezek. Ljubljana.

Gams, I. 1989d: Geografija. Enciklopedija Slovenije, 3. zvezek. Ljubljana.

Gams, I. 1989e: Geografsko društvo Slovenije. Enciklopedija Slovenije, 3. zvezek. Ljubljana.

Gams, I. 1989f: Geografsko okolje. Enciklopedija Slovenije, 3. zvezek. Ljubljana.

Gams, I. 1989g: Gure. Enciklopedija Slovenije, 3. zvezek. Ljubljana.

Gams, I. 1989h: Imena držav. Delo, 21. 1. 1989. Ljubljana.

Gams, I. 1989i: Termini za premikanje zemeljskih gmot. Geografski vestnik 61. Ljubljana.

Gams, I. 1989j: Terminologija premikanja zemeljskih gmot. Ujma 3. Ljubljana.

Gams, I. 1990a: Hotenjsko podolje. Enciklopedija Slovenije, 4. zvezek. Ljubljana.

Gams, I. 1990b: Ilešič, Svetozar. Enciklopedija Slovenije, 4. zvezek. Ljubljana.

Gams, I. 1990c: Jugoslavija. 2, Prirodna osnova. Reljef. Enciklopedija Jugoslavije, 6. knjiga. Zagreb.

Gams, I. 1990d: Julijske Alpe. Enciklopedija Jugoslavije, 6. knjiga. Zagreb.

Gams, I. 1990e: Karavanke. Enciklopedija Jugoslavije, 6. knjiga. Zagreb.

Gams, I. 1990f: Naravni pogoji v ozadju zgodovine Izraela. Geografski obzornik 37-1. Ljubljana.

Gams, I. 1990g: O imenu obalne regije. Geografski vestnik 62. Ljubljana.

Gams, I. 1990h: Ob šestdesetletnici prof. dr. Igorja Vrišerja. Geografski vestnik 62. Ljubljana.

Gams, I. 1990i: Skozi Srednjo Evropo v Evropo? Zgodba o simbolih in zemljepisnih imenih. Nova revija 101/102. Ljubljana.

Gams, I. 1991a: Analiza imen za obalno regijo. Annales 1-1. Koper.

Gams, I. 1991b: Kako do uspešnih novih občin. Delo, Sobotna priloga, 30.11. 1991. Ljubljana.

Gams, I. 1991c: Klopinjsko jezero. Enciklopedija Slovenije, 5. zvezek. Ljubljana.

Gams, I. 1991d: Komna. Enciklopedija Slovenije, 5. zvezek. Ljubljana.

Gams, I. 1991e: Koroška, Kärnten. Enciklopedija Slovenije, 5. zvezek. Ljubljana.

Gams, I. 1991f: Kotlina. Enciklopedija Slovenije, 5. zvezek. Ljubljana.

Gams, I. 1991g: Kranjc, Andrej. Enciklopedija Slovenije, 5. zvezek. Ljubljana.

Gams, I. 1991h: Kraška jama. Enciklopedija Slovenije, 5. zvezek. Ljubljana.

Gams, I. 1991i: Kraške reliefne oblike. Enciklopedija Slovenije, 5. zvezek. Ljubljana.

Gams, I. 1991j: Kraško polje. Enciklopedija Slovenije, 5. zvezek. Ljubljana.

Gams, I. 1991k: Misli pred novim spreminjanjem študijskega načrta geografije na FF. Geografski obzornik 38-1. Ljubljana.

Gams, I. 1991l: Poplave - povodenj - ujma. Ujma 5. Ljubljana.

Gams, I. 1991m: Proslava stoletnice rojstva Antona Melika (1.1.1890-5.6. 1966). Geografski vestnik 62. Ljubljana.

Gams, I. 1991n: Sistemi prilagoditve primorskega dinarskega krasa na kmetijsko rabo tal = Systems of adapting the littoral Dinaric Karst to agrarian land use. Geografski zbornik 31. Ljubljana.

Gams, I. 1991o: The origin of the term karst in the time of transition of karst (kras) from deforestation to forestation. Proceedings of the international conference on environmental changes in karst areas. Padova.

Gams, I. 1992a: Ferdinand Seidl - predhodnik slovenske znanstvene regionalne geografije. Geografski vestnik 64. Ljubljana. 
Gams, I. 1992b: Kako umiriti tretjo balkansko vojno? Delo, Praznična priloga, 31.12. 1992. Ljubljana. Gams, I. 1992c: Labotska dolina. Enciklopedija Slovenije, 6. zvezek. Ljubljana.

Gams, I. 1992d: Ljubljanska kotlina. Enciklopedija Slovenije, 6. zvezek. Ljubljana.

Gams, I. 1992e: Ljubljansko polje. Enciklopedija Slovenije, 6. zvezek. Ljubljana.

Gams, I. 1992f: Lovrenška jezera. Enciklopedija Slovenije, 6. zvezek. Ljubljana.

Gams, I. 1992g: Mangart. Enciklopedija Slovenije, 6. zvezek. Ljubljana.

Gams, I. 1992h: Manohin, Vital. Enciklopedija Slovenije, 6. zvezek. Ljubljana.

Gams, I. 1992i: Pisati o znanosti. Slovenec, 12.5. 1992. Ljubljana.

Gams, I. 1993a: Igor Vrišer. Letopis Slovenske akademije znanosti in umetnosti, 44. knjiga. Ljubljana.

Gams, I. 1993b: Nekatere družbene spremembe po popisu 1. 1991 (dopolnilo k učbeniku Geografske značilnosti Slovenije). Geografija v šoli 3. Ljubljana.

Gams, I. 1993c: O značaju pouka geografije Slovenije v osnovni in srednji šoli. Geografija v šoli 3. Ljubljana. Gams, I. 1993d: Ob šestdesetletnici prof. dr. Jurija Kunaverja. Geografski vestnik 65. Ljubljana.

Gams, I. 1993e: Ob vprašanju imen (Notranjska) Reka in (Notranjski) Snežnik. Geografski vestnik 65. Ljubljana.

Gams, I. 1993f: Origin of the term »karst « and the transformation of the Classical Karst (Kras). Environment Geology 21-3. Berlin, Heidelberg.

Gams, I. 1993g: Poimenovanje Reke. Slovenec, 23. 12. 1993. Ljubljana.

Gams, I. 1994a: Dr. Petru Habiču ob šestdesetletnici. Geografski vestnik 66. Ljubljana.

Gams, I. 1994b: Koroška med mitom in stvarnostjo. Na kaj opreti gospodarski napredek? Koroška in znamenja časa. Ljubljana.

Gams, I. 1994c: Obir. Enciklopedija Slovenije, 8. zvezek. Ljubljana.

Gams, I. 1994d: Ojstrica, naselje nad Dravogradom. Enciklopedija Slovenije, 8. zvezek. Ljubljana.

Gams, I. 1994e: Olševa. Enciklopedija Slovenije, 8. zvezek. Ljubljana.

Gams, I. 1994f: Osojske Ture. Enciklopedija Slovenije, 8. zvezek. Ljubljana.

Gams, I. 1994g: Osojsko jezero. Enciklopedija Slovenije, 8. zvezek. Ljubljana.

Gams, I. 1994h: Pojem in obseg doline v slovenski regionalni geografiji. Geografski vestnik 66. Ljubljana. Gams, I. 1994i: S praznoverjem v Evropo 20. stoletja. Delo, Sobotna priloga, 28. 1. 1994. Ljubljana.

Gams, I. 1994j: Spremenljivi pomen Krasa za krasoslovje med razvojem pojma kras. Annales 4-4. Koper. Gams, I. 1994k: Za varnejši svet 21. stoletja. Delo, Znanje za razvoj, 12. 10. 1994. Ljubljana.

Gams, I. 1995a: Dr. geogr. znan. Ivan Gams, prof. geogr., red. prof. za fizično geografijo. Biografije in bibliografije učiteljev in sodelavcev, 4. knjiga, 1. del. Ljubljana.

Gams, I. 1995b: Kaj pomeni beseda »kras«?: razvoj slovenske besede kras v mednarodni termin do konca 19. stoletja. Kras 2-10. Ljubljana.

Gams, I. 1995c: Korenine mojega odnosa do drugačnih. Edina prava ljubezen je ljubezen do drugačnih. Ljubljana. Gams, I. 1995d: Ob izvolitvi dr. Andreja Kranjca za dopisnega člana SAZU. Naše jame 37. Ljubljana.

Gams, I. 1995e: Plebiscit kot loterija. Delo, 4.2. 1995. Ljubljana.

Gams, I. 1995f: Podgorje. Enciklopedija Slovenije, 9. zvezek. Ljubljana.

Gams, I. 1995g: Podjuna. Enciklopedija Slovenije, 9. zvezek. Ljubljana.

Gams, I. 1995h: Podpeč, Podpeško jezero. Enciklopedija Slovenije, 9. zvezek. Ljubljana.

Gams, I. 1995i: Pokrajina. Enciklopedija Slovenije, 9. zvezek. Ljubljana.

Gams, I. 1995j: Predalpski svet. Enciklopedija Slovenije, 9. zvezek. Ljubljana.

Gams, I. 1995k: Preseško jezero. Enciklopedija Slovenije, 9. zvezek. Ljubljana.

Gams, I. 1995l: Sedemdeset let Geografskega vestnika. Geografski vestnik 67. Ljubljana.

Gams, I. 1996a: Andrej Kranjc. Letopis Slovenske akademije znanosti in umetnosti, 46. knjiga. Ljubljana.

Gams, I. 1996b: Dr. Drago Meze, sedemdesetletnik. Delo, 22. 1. 1996. Ljubljana.

Gams, I. 1996c: Ob desetletnici smrti prof. dr. Svetozarja Ilešiča. Geografija v šoli 5-2. Ljubljana.

Gams, I. 1996d: Radinja, Darko. Enciklopedija Slovenije, 10. zvezek. Ljubljana.

Gams, I. 1996e: Regionalna geografija. Enciklopedija Slovenije, 10. zvezek. Ljubljana.

Gams, I. 1996f: Reka, večji, navadno daljši vodni tok, 10. zvezek. Ljubljana.

Gams, I. 1996g: Relief. Enciklopedija Slovenije, 10. zvezek. Ljubljana.

Gams, I. 1996h: Sedemdesetletnica Draga Mezeta. Geografski vestnik 68. Ljubljana.

Gams, I. 1996i: Spomini. Odsevanja 14-26. Slovenj Gradec.

Gams, I. 1996j: Termin kras. Naše jame 38. Ljubljana.

Gams, I. 1997a: Prof. dr. Darko Radinja 70-letnik. Delo, 12.2. 1997. Ljubljana. 
Gams, I. 1997b: Sedemdeset let prof. dr. Darka Radinje. Geografski vestnik 69. Ljubljana.

Gams, I. 1997c: Slovenj Gradec, mesto, občinsko središče. Enciklopedija Slovenije, 11. zvezek. Ljubljana. Gams, I. 1997d: Slovenjgraška kotlina. Enciklopedija Slovenije, 11. zvezek. Ljubljana.

Gams, I. 1998a: Dušan Novak (1931-1998). Geografski vestnik 70. Ljubljana.

Gams, I. 1998b: Koliko slovenskih pokrajin? Delo, Sobotna priloga, 17. 10. 1998. Ljubljana.

Gams, I. 1998c: Stari trg. Enciklopedija Slovenije, 12. zvezek. Ljubljana.

Gams, I. 1998d: Strojna, naselje samotnih kmetij ... Enciklopedija Slovenije, 12. zvezek. Ljubljana.

Gams, I. 1998e: Strojna, obmejno hribovje ... Enciklopedija Slovenije, 12. zvezek. Ljubljana.

Gams, I. 1999a: Govor ob odkritju spominske plošče profesorju Svetozarju Ilešiču, Ljubljana, Trstenjakova ulica 9, 4.2.1999. Geografski vestnik 71. Ljubljana.

Gams, I. 1999b: Šentanel. Enciklopedija Slovenije, 13. zvezek. Ljubljana.

Gams, I. 2000: Vrbsko jezero. Enciklopedija Slovenije, 14. zvezek. Ljubljana.

Gams, I. 2001a: Koroška pokrajina, Gospodarskogeografski pregled. Koroška pokrajina. Ravne na Koroškem. Gams, I. 2001b: O Afganistancih in drugih gorjancih. Geografski vestnik 73-2. Ljubljana.

Gams, I. 2002a: Andrej Kranjc. Letopis Slovenske akademije znanosti in umetnosti, 52. knjiga. Ljubljana. Gams, I. 2002b: Rekviem za Baško grapo. Delo, Sobotna priloga, 16.3.2002. Ljubljana.

Gams, I. 2002c: Speleolog Wilhelm Puttik. Speleo 35. Praha.

Gams, I. 2002d: Sporne makroregije v novem gimnazijskem učbeniku za Slovenijo. Geografija v šoli 11-2. Ljubljana.

Gams, I. 2002e: V spomin Slavi Rakovec (1912-2002), Žale, Ljubljana, 19.4. 2002. Geografski vestnik 74. Ljubljana. Gams, I. 2003: Ob sedemdesetletnici dr. Jurija Kunaverja: Ljubljana, 13.6.2003. Geografski vestnik 75-1. Ljubljana. Gams, I. 2005a: Anton Melik, Kras in kras: ob 40-letnici smrti akademika prof. dr. Antona Melika. Kras 76. Komen.

Gams, I. 2005b: Geografski terminološki slovar. Ljubljana.

Gams, I. 2005c: O pomenu Antona Melika za slovensko geografijo. Geografski vestnik 78. Ljubljana.

Gams, I. 2007: Pokrajina, krajina in regija v luči geografskega terminološkega slovarja. Dela 28. Ljubljana.

Gams, I. 2008: The 100th birth anniversary of professor Svetozar Ilešič (1907-1985). Acta carsologica 37-1. Ljubljana.

Gams, I., Ajdič, G., Ferenc, T. 1987: Bloke. Enciklopedija Slovenije, 1. zvezek. Ljubljana.

Gams, I., Buser, S., Sagadin, M., Žonta, M. 1989: Gorenjska. Enciklopedija Slovenije, 3. zvezek. Ljubljana. Gams, I., Čas, M., Wraber, T. 1994: Peca. Enciklopedija Slovenije, 8. zvezek. Ljubljana.

Gams, I., Gabrovec, M. 1999: Land use and human impact in the Dinaric karst. Karst and agriculture in the world. Roma.

Gams, I., Gospodarič, R., Sket, B., Gregori, J. 1988: Cerkniško jezero. Enciklopedija Slovenije, 2. zvezek. Ljubljana. Gams, I., Grafenauer, B. 1992: Krka. Enciklopedija Slovenije, 6. zvezek. Ljubljana.

Gams, I., Habič, P., Klemenčič, V., Kunaver, J., Lah, A., Radinja, D., Vrišer, I. 1981: Razprava o geografiji. Geografski vestnik 53. Ljubljana.

Gams, I., Hozjan, A. 1993: Mislinja, naselje ... Enciklopedija Slovenije, 7. zvezek. Ljubljana.

Gams, I., Kladnik, D., Gajšek, M., Hazler, V., Bogataj, J. 1996: Regionalizacija. Enciklopedija Slovenije, 10. zvezek. Ljubljana.

Gams, I., Kranjc, A. 2004: Jean Nicod. Letopis Slovenske akademije znanosti in umetnosti, 54. knjiga. Ljubljana. Gams, I., Linasi, M. 1994: Pameče. Enciklopedija Slovenije, 8. zvezek. Ljubljana.

Gams, I., Linasi, M. 1996: Rož. Enciklopedija Slovenije, 10. zvezek. Ljubljana.

Gams, I., Linasi, M. 1998: Svinja. Enciklopedija Slovenije, 12. zvezek. Ljubljana.

Gams, I., Lovrenčak, F., Ingolič, B. 1971: Krajna vas: študija o prirodnih pogojih in agrarnem izkoriščanju Krasa. Geografski zbornik 12. Ljubljana.

Gams, I., Marušič, B. 1995: Primorska. Enciklopedija Slovenije, 9. zvezek Ljubljana.

Gams, I., Mlinšek, D., Oder, K. 1999: Topla. Enciklopedija Slovenije, 13. zvezek. Ljubljana.

Gams, I., Pavlovec, R., Kastelic, J., Lah, A. 1987: Alpe. Enciklopedija Slovenije, 1. zvezek. Ljubljana.

Gams, I., Petkovšek, Z. 1990: Inverzija. Enciklopedija Slovenije, 4. zvezek. Ljubljana.

Gams, I., Placer, L., Marinček, L., Wraber, T. 1995: Posavsko hribovje. Enciklopedija Slovenije, 9. zvezek. Ljubljana.

Gams, I., Ramovš, A. 1990a: Julijske Alpe. Enciklopedija Slovenije, 4. zvezek. Ljubljana.

Gams, I., Ramovš, A. 1990b: Kamniško-Savinjske Alpe. Enciklopedija Slovenije, 4. zvezek. Ljubljana. 
Gams, I., Ramovš, A., Križnar, I. 1990: Karavanke. Enciklopedija Slovenije, 4. zvezek. Ljubljana.

Gams, I., Resnik Planinc, T., Saarinen, T. F. 1993: Poznavanje držav sveta pri slovenskih in tujih dijakih. Geografija v šoli 3. Ljubljana.

Gams, I., Skoberne, P. 1997a: Slovenj Gradec. Občina Mislinja. Enciklopedija Slovenije, 11. zvezek. Ljubljana. Gams, I., Skoberne, P. 1997b: Slovenj Gradec. Občina Slovenj Gradec. Enciklopedija Slovenije, 11.zvezek. Ljubljana. Gams, I., Stopar, I. 1994: Ostrovica. Enciklopedija Slovenije, 8. zvezek. Ljubljana.

Gams, I., Šašel, J. 1985: Cerknica. Enciklopedija Jugoslavije, 2. knjiga. Zagreb.

Gams, I., Šircelj, V. 1970: O opremljenosti šol za pouk geografije in o virih zanj: (rezultati ankete GDS v januarju 1970). Geografski obzornik 17-3/4. Ljubljana.

Gams, I., Štrucl, I. 1991: Koroška. Enciklopedija Slovenije, 5. zvezek. Ljubljana.

Gams, I., Šušteršič, F. 1991: Krasoslovje. Enciklopedija Slovenije, 5. zvezek. Ljubljana.

Gams, I., Toman, M. J. 1995: Potok. Enciklopedija Slovenije, 9. zvezek. Ljubljana.

Gams, I., Urbanek, J., Povž, M., Zupan, M. 1993: Mislinja, desni pritok ... Enciklopedija Slovenije, 7. zvezek. Ljubljana.

Gams, I., Vrhovšek, D. 1990: Jezero. Enciklopedija Slovenije, 4. zvezek. Ljubljana.

Gams, I., Wraber, T. Kunc, A. 2000: Uršlja gora. Enciklopedija Slovenije, 14. zvezek. Ljubljana.

Gams, I., Zupan, M., Povž, M. 1994: Paka. Enciklopedija Slovenije, 8. zvezek. Ljubljana.

Gams, I., Ževart, M. 1993: Mislinjska dolina. Enciklopedija Slovenije, 7. zvezek. Ljubljana.

Gams, I., Ževart, M. 1994: Otiški Vrh. Enciklopedija Slovenije, 8. zvezek. Ljubljana.

Gams, I., Ževart, M. 1999a: Šmartno pri Slovenj Gradcu. Enciklopedija Slovenije, 13. zvezek. Ljubljana.

Gams, I., Ževart, M. 1999b: Štajerska. Enciklopedija Slovenije, 13. zvezek. Ljubljana.

Gavrilović, D. (urednik) 1974: Srpska kraška terminologija. Beograd.

Kladnik, D. 2006: Tuja zemljepisna imena v slovenskem jeziku; razvojni vidiki in problematika njihove rabe. Doktorska disertacija, Oddelek za geografijo Filozofske fakultete Univerze v Ljubljani. Ljubljana.

Kladnik, D. 2012: Slovenian geography and geographical names. Geografski vestnik 84-1. Ljubljana.

Kladnik, D., Lovrenčak, D., Orožen Adamič, M. (uredniki) 2005: Geografski terminološki slovar. Ljubljana.

Klemenčič, V. 2010: O Vrišerjevih dilemah in dejanskem stanju slovenske geografije v času delovanja tretje generacije slovenskih geografov. Geografski vestnik 82-2. Ljubljana.

Kranjc, A. 2013: Ivan Gams - karstologist. Acta geographica Slovenica 53-1. Ljubljana. DOI: 10.3986/AGS53101

Kunaver, J. 1973: O razvoju slovenske terminologije za mikroreliefne kraške oblike (Nekaj misli in predlogov ob primeru visokogorskega krasa). Slovenska kraška terminologija. Ljubljana.

Kunaver, J. 1984: O nekaterih problemih zbiranja in uporabe zemljepisnih imen v slovenskih Alpah. Zbornik radova savjetovanja o pitanjima standardizacije geografskih naziva u jezicima naroda i narodnosti SFRJ. Sarajevo.

Kunaver, J. 2005: Življenje in delo akademika Ivana Gamsa. Bibliografija akademika Ivana Gamsa (sestavile in uredile Račič Knez, I., Strgar Mlinar, M., Turk, J.). Bibliografije akademikov 1. Ljubljana.

Medved, J., Gams, I. 1968: Ojstrica nad Dravogradom: (primer preobrazbe gorskega kraja zaradi prevrednotenja naravnih in družbenih razmer). Geografski vestnik 40. Ljubljana.

Melik, A. 1928: Pisava krajevnih imen. Geografski vestnik 4. Ljubljana.

Novak, D., Šušteršič, F. 1974: Slovenska kraška terminologija. Kraška terminologija jugoslovanskih narodov, 1. Geografski vestnik 46. Ljubljana.

Orožen Adamič, M., Perko, D., Kladnik, D. (uredniki) 1995: Krajevni leksikon Slovenije. Ljubljana.

Orožen Adamič, M., Perko, D., Kladnik, D. (uredniki) 1996: Priročni krajevni leksikon Slovenije. Ljubljana.

Pagon, V., Gams, I. 1971: HE in bistra hči planin. Delo, 20.3. 1971. Ljubljana.

Perko, D. 2013: Contribution of Ivan Gams to Slovenia's regional geography and regionalization. Acta geographica Slovenica 53-2. Ljubljana. DOI: 10.3986/AGS53201

Roglić, J. 1974: Prilog hrvatskoj krškoj terminologiji. Zagreb.

Savnik, R. 1980: Krajevni leksikon Slovenije, 4. knjiga. Ljubljana.

Zavrnik, B., Strnad, J., Gams, I., Geč, F., Kurinčič-Tomšič, M. 1993: Naglo sodišče na Novem trgu 3/I: spopad med znanostjo in paraznanostjo. Delo, 26.6.1993. Ljubljana.

Vrišer, I. 2007: Geografske dileme. Geografski vestnik 79-1. Ljubljana.

Zorn, M., Komac, B. 2013: Contribution of Ivan Gams to Slovenian physical geography and geography of natural hazards. Acta geographica Slovenica 53-1. Ljubljana. DOI: 10.3986/AGS53102 


\section{Ivan Gams - terminolog, encikloped, biograf in še kaj}

DOI: $10.3986 /$ AGS53200

UDK: 929Gams I.:91

COBISS: 1.02

IZVLEČEK: V drugi polovici 20. stoletja je slovensko geografijo zaznamovala postopna specializacija z usmerjanjem posameznikov v čedalje ožja področja znanstvenega zanimanja. Pri tem akademik Ivan Gams ni bil izjema, saj se je v svojem znanstvenem in pedagoškem delu poglobljeno lotil krasoslovja. Vseskozi je ohranjal izjemno znanstveno širino, kar se odraža $v$ široki paleti njegovih prispevkov $z$ vseh področij fizične geografije, odlikoval se je tudi kot regionalni geograf. Ob tem nekako zbledi njegov velik prispevek na preostalih področjih geografije. V njem se odraža vseskozi nemirni in kritični znanstveni duh, s katerim je dejavno sooblikoval naše polpreteklo družbeno dogajanje. Zunaj fizične geografije je bil Gams posebno dejaven na področjih zemljepisnih izrazov in imen.

KLJUČNE BESEDE: Ivan Gams, terminologija, zemljepisna imena, leksikon, enciklopedija, kronika, Slovenija

Uredništvo je prispevek prejelo 14. aprila 2013.

NASLOV:

dr. Drago Kladnik

Geografski inštitut Antona Melika

Znanstvenoraziskovalni center Slovenske akademije znanosti in umetnosti

Gosposka ulica 13, SI - 1000 Ljubljana, Slovenija

E-pošta: drago.kladnik@zrc-sazu.si

\section{Vsebina}

2 Gamsov prispevek h geografski terminologiji

Gamsov prispevek k zemljepisnim imenom 236

Družbenogeografski in idejni prispevki 237

Leksikonski in enciklopedični prispevki 238

Biografski prispevki 239

Uredniško delo 240

Sklep 240

Literatura 240 


\section{Uvod}

Ivan Gams je najvidnejši predstavnik tretje generacije slovenskih geografov oziroma generacije geografov, ki so diplomirali po drugi svetovni vojni (Vrišer 2007). Obdobje te generacije slovenskih geografov sovpada s socialističnim družbenim redom, z osamosvojitvijo Slovenije leta 1991 pa je primat prevzela četrta generacija slovenskih geografov, ki jo počasi že izpodrivajo pripadniki pete generacije.

Za čas po drugi svetovni vojni so značilni postopna specializacija z usmerjanjem posameznikov v čedalje ožja področja znanstvenega zanimanja, vznik novih geografskih izobraževalnih in znanstvenih ustanov in geografskih znanstvenih panog, izhajati so začele nove znanstvene in strokovne revije. Slovenski geografi so imeli znotraj Jugoslavije na nek način vodilno vlogo, saj so imeli razvejene mednarodne stike in so skrbeli za uveljavljanje sodobne geografske teorije in metod.

Mnenja o dosežkih tretje generacije slovenskih geografov so deljena. Vrišer (2007) kritično ugotavlja, da se je premalo postorilo na temeljnem geografskem problemu, kako znanstveno razložiti, izmeriti in utemeljiti povezanost geografskih prvin in dejavnikov v pokrajini, očita tudi močno prevlado analitskega pristopa, kar je vodilo v drobljenje geografije in obravnavo zgolj nekaterih pokrajinskih sestavin. Na drugi strani je Klemenčič (2010) prepričan, da je bilo njeno poslanstvo uspešno, saj so njeni številni pripadniki pomembno prispevali k povečanemu družbenemu ugledu geografije. Vrišer vidi krono geografske ustvarjalnosti v regionalni geografiji, Klemenčič pa pri preučevanju pokrajine v ospredje postavlja problemski pristop, ki zahteva ožjo znanstveno specializacijo.

Ivan Gams je združeval oba koncepta geografske misli. Na eni strani se je aktivno zavzemal za regionalno geografijo (Perko 2013), na drugi pa se je kmalu specializiral v krasoslovje. Pri tem je ohranjal neverjetno znanstveno in strokovno širino, kar se odraža ne le v njegovem zanimanju za krasoslovje (Kranjc 2013) in druge panoge fizične geografije in njihovem raziskovanju (Zorn in Komac 2013), ampak tudi v zanimanju za družbeno geografijo. Svoja stališča je izrazil tudi na področjih znanstvenega udejstvovanja, organiziranosti geografije in njenega poučevanja. Vseskozi pa je bil tudi družbeno angažiran, zato se je izkazal kot biograf in kronist, pisec številnih enciklopedičnih prispevkov in skrbnik klenega slovenskega jezika, pri čemer se je dejavno angažiral pri posodabljanju pravil za slovenski pravopis in ustrezni rabi zemljepisnih imen, zlasti tujih. Poseben odnos je imel do slovenskih gora, izkazal se je tudi kot človekoljub.

Slika 1: Gamsovi prispevki zunaj fizične geografije, krasoslovja in regionalne geografije glede na tematiko in strokovno raven obravnave. Glej angleški del prispevka.

\section{Gamsov prispevek h geografski terminologiji}

Slovenski zemljepisni izrazi so se začeli pojavljati v prvih slovenskih učbenikih iz prve polovice 19. stoletja. Značilen primer je Cigaletova Znanstvena terminologija iz leta 1880, ki je v bistvu nemško-slovenski slovar izrazja različnih znanstvenih področij, tudi geografskih. Potreba po ureditvi vztrajno rastočega obsega geografskega izrazja je odsevala v programu odbora Geografskega društva v Ljubljani za leto 1925, ko so njegovi člani imeli v mislih sestavo enotne slovenske geografske terminologije. Ker za njeno pripravo takrat niso imeli dovolj izkušenj, je ostalo zgolj pri neuresničenih zamislih. O terminoloških zadregah so spregovorili na prvem kongresu jugoslovanskih geografov aprila 1927 v Beogradu (Kladnik, Lovrenčak in Orožen Adamič 2005). Veliko izrazov o površinskih oblikah, vodovju, rastlinstvu, poteh in podobnem je v knjigi Ljudska geografija, s podnaslovom Terensko izrazoslovje, ki je izšla leta 1953, zbral Rudolf Badjura. Prav s poročilom o tej knjigi v Naših razgledih je Gams (1953a) začel svoje terminološko poslanstvo.

Po 2. svetovni vojni je bila na Inštitutu za slovenski jezik Slovenske akademije znanosti in umetnosti ustanovljena terminološka komisija. Gradivo se je zbiralo z izpisovanjem strokovnih izrazov iz slovenske strokovne literature. Med izpisovalci je bil tudi Ivan Gams, ki se je ob tem podrobneje seznanil s terminološko problematiko. Leta 1964 sta bila izdelana dva seznama, in sicer 130 strani obsegajoč seznam izpisanih terminov ter seznam del, iz katerih so bili izpisani. Pozneje je Gams skupaj z Ilešičem sodeloval pri redakciji in pripravi geografskih gesel za Slovar slovenskega knjižnega jezika, ki je v petih knjigah izšel med letoma 1970 in 1991 (Kladnik, Lovrenčak in Orožen Adamič 2005).

Ponovna odločitev o izdelavi geografskega terminološkega slovarja je bila sprejeta leta 1982, nalogo koordinatorja pa je prevzel Ivan Gams. Tovrstne zapise je objavljal že v petdesetih in še bolj v šestdesetih 
letih prejšnjega stoletja (Gams 1955c, 1961a, 1962b, 1962c, 1962e, 1963b, 1963d, 1964a, 1967d, 1968d in 1970c). V Gamsu in sodelavcih je dozorela misel o izdaji samostojnega knjižnega dela, namenjenega ne le slovenski, ampak tudi drugi jugoslovanski strokovni javnosti. V okviru Zveze geografskih ustanov Jugoslavije je bil oktobra 1971 na ljubljanski Filozofski fakulteti izveden prvi jugoslovanski simpozij o kraški terminologiji in tipologiji kraških terenov (Gams 1971a in 1973c, 34), ki se ga je udeležilo 20 strokovnjakov.

Gams je dosegel svoj terminološki vrh z izidom Slovenske kraške terminologije (Gams 1973c), v kateri se je podpisal kot glavni urednik, V njej je najprej sedemjezični (slovenski, srbski, hrvaški, makedonski, angleški, nemški in francoski) seznam izrazov, potem je podrobneje razložen njihov pomen, sledita še historiat nastanka terminologije in predstavitev nekaterih najbolj relevantnih referatov z ljubljanskega simpozija (Gams 1973a in 1973b; Kunaver 1973). Leto za slovensko različico kraške terminologije sta izšli njeni srbska (Gavrilović 1974) in hrvaška (Roglić 1974) različica, medtem ko je načrtovana makedonska terminologija ostala le na idejni ravni.

Kot najbolj agilen snovalec kraške teminologije se je Gams leto po njenem izidu spustil v polemiko z geologom Francetom Šušteršičem (Gams 1974b), ki je skupaj z Dušanom Novakom objavilo njeno oceno v Geografskem vestniku (Novak in Šušteršič 1974). S tem se njegovo delo pri razčiščevanju pomena kraškega izrazja in njegovi promociji ni zaključilo; poleg objav v domačih publikacijah (Gams 1976a, 1979a, 1980b, 1994j, 1995b in 1996j) obsega tudi zapise v tujih enciklopedijah (Gams 1968b), kongresnih zbornikih (Gams 1977d, 1989a in 1991o) in znanstveni periodiki (Gams 1993f), kar izpričuje njegovo mednarodno uglednost.

Sicer pa se je Gams že zgodaj začel ukvarjati tudi z drugim izrazjem, zlasti geomorfološkim (Gams 1956e in 1964b) in gorniškim (Gams 1965). Precej pozornosti je namenil okoljskim terminološkim razčiščevanjem (Gams 1976b in 1977b). Zatem se je znova posvetil geomorfološkim terminološkim izzivom (Gams 1986g, 1989i, 1989j in 1994h) in vprašanjem s področja naravnih nesreč (Gams 1991l).

Tovrstno zanimanje je zagotovo povezano z njegovim delom pri Geografskem terminološkem slovarju (Kladnik, Lovrenčak in Orožen Adamič 2005), o katerem je ob polemiziranju pomena pojmov pokrajina, krajina in regija poročal v enem od svojih zadnjih zapisov (Gams 2007). Oktobra 1983 je Gams kot koordinator projekta pisno seznanil sodelavce s podrobneje opredeljenimi izhodišči za izbor terminov, ki naj bi bili predstavljeni v njem. Čeprav Gams pri njegovi finalizaciji ni sodeloval, je več kot opazen njegov vsebinski prispevek, saj je pripravil gesla s področij geografije krasa, geomorfologije, klimatogeografije in splošne geografije (Gams 2005b).

\section{Gamsov prispevek k zemljepisnim imenom}

Slovenci smo že razmeroma zgodaj dobili prvi atlas sveta, ki je izhajal v snopičih (Atlant 1869-1877). Za njegovo redakcijo je poskrbel pravnik in jezikoslovec Matej Cigale. Cigaletov sodobnik je bil naravoslovno izobražen vrhunski avstrijski kartograf, Slovenec Blaž Kocen (Blasius Kozenn), katerega atlasi so doživeli številne ponatise in izšli v šestih jezikih, $v$ še več jezikih pa njihove sodobnejše koprodukcijske izdaje, vendar med njimi ni bilo nobene v slovenščini (Bratec Mrvar s sodelavci 2011).

Prvi geograf, ki je sistemsko opozoril na težave pri zapisovanju tujih krajevnih imen je bil Anton Melik (1928). Od takrat slovenske geografe zemljepisno imenoslovje še kako zanima, čeprav se večina z njim srečuje in ukvarja le vzporedno, ker je specializirana v druge geografske panoge (Kladnik 2012).

Geografi se že od začetka sedemdesetih let prejšnjega stoletja načeloma zavzemamo za prevladujočo rabo originalnih imen, kar je v določeni meri navzkriž z bogatim izročilom slovenskega jezika na področju tovrstne rabe. Pri tem je bil najbolj angažiran in izpostavljen geograf prav Ivan Gams, ki se je vseskozi zavzemal tudi za standardizacijo zemljepisnih imen in ob tem za poenostavitve pri rabi velike in male začetnice v zemljepisnih imenih. Gamsov prvi članek o zemljepisnih imenih, v katerem opozarja na neenotno rabo slovenskih eksonimov, je izšel sredi šestdesetih let (Gams 1964c).

Jezikoslovci so geografom sem in tja prisluhnili, največkrat pa so njihove pobude zavrnili (Kladnik 2006, 31-40). V javnosti se je ustvaril vtis, da gre za hud spor med strokama.

Slika 2: Gams je zelo zavzeto razpravljal o ustreznem poimenovanju pokrajine v zaledju slovenskega dela Jadranskega morja.

Glej angleški del prispevka. 
Nesporazume ni povzročalo le različno mnenje o primerni rabi tujih zemljepisnih imen in recipročno o ustreznih zapisih slovenskih zemljepisnih imen $\mathrm{v}$ tujini, ampak tudi pisanje velike in male začetnice $\mathrm{v}$ večbesednih imenih. Jezikoslovci so premalo zavzeto prisluhnili geografom, ki so zaradi sprejetih mednarodnih obveznosti skušali slediti priporočilom resolucij OZN v zvezi z zemljepisnimi imeni, predvsem tistim o rabi eksonimov. Geografi so morda premalo upoštevali bogato slovensko izročilo podomačevanja tujih zemljepisnih imen, na drugi strani pa so zaradi zgodovinskega spomina goreče zavračali eksonime s slovenskega ozemlja, še zlasti v nemščini in italijanščini.

Leta 1971 je v Geografskem društvu Slovenije dozorel sklep, da je treba poenostaviti pravila o pisavi zemljepisnih imen. Društvo se je pod organizacijskim vodstvom Ivana Gamsa obrnilo na Inštitut za Slovenski jezik SAZU, da bi skupaj pripravili javni posvet o rabi zemljepisnih imen (Gams 1972g, 1972h in 1972j).

Leta 1981 je izšel Načrt pravil za novi slovenski pravopis. V zvezi s tem je znanstvena sekcija Geografskega društva Slovenije organizirala javni posvet o vprašanjih rabe zemljepisnih imen. Izpostavljeno je bilo (Gams 1984d), da slovenski geografi nasprotujejo uveljavljanju načela "piši kot govorijo«, da nasprotujejo predlagani transliteraciji latiničnih pisav v slovenščino ter skladno s priporočili OZN in zaradi povsem praktičnih komunikacijskih razlogov ne podpirajo naraščanja števila eksonimov (1982c, Gams 1982e in 1982f).

Geografska komisija se je preoblikovala v Komisijo za geografska imena v okviru Geografskega društva Slovenije, ki jo je vodil Ivan Gams. Med drugim je zapisal (Gams 1984b in 1985o), da so se problema standardizacije zemljepisnih imen prvi zavedli prav geografi, ki so že v sklepih prvega mednarodnega geografskega kongresa leta 1871 izpostavili potrebo po njihovi mednarodni standardizaciji.

O posvetovanju o vprašanjih standardizacije zemljepisnih imen v jezikih narodov in narodnosti SFRJ, organiziranem v Sarajevu leta 1984 (Gams 1984d in 1984e; Kunaver 1984), je Gams med drugim zapisal (Gams 1984d, 121): "Za mnoge udeležence, tudi jezikoslovce in geografe, so bila poročila o mednarodnih prizadevanjih za standardizacijo novost. "O zmedi in samovolji pri uporabi pokrajinskih imen je objavil več zapisov v javnih občilih (Gams 1986d) in znanstvenih revijah (Gams 1987j, 1990g in 1991a).

Občasno se je še obregnil ob po njegovem neustrezno rabo velike in male v zemljepisnih imenih (Gams 1990i), dotaknil se je standardizacije slovenskih imen držav (Gams 1989h), ljuba pa mu je bila tematika ustrezne rabe določenih konkretnih imen (Gams 1989b), kakršni sta hidronim Reka (Gams 1993e in 1993g) in oronim Snežnik (Gams 1993e). Njegova izjemno poznavanje rodne pokrajine in prefinjen občutek za zemljepisna imena sta bila gotovo razlog, da so ga, kljub nesporazumom z jezikoslovci, prav ti pri snovanju leksikona Slovenska krajevna imena povabili k sodelovanju kot najbolj kompetentnega informatorja za ustrezen zapis krajevnih imen na območjih tedanjih občin Dravograd in Slovenj Gradec (Gams 1985g in $1985 \mathrm{k})$.

Slika 3: Eden prvih Gamsovih člankov o tujih deželah obravnava Ljudsko republiko Kitajsko. Na fotografiji so kmetovalci na terasiranih riževih poljih v južnem Yunnanu.

Glej angleški del prispevka.

\section{Družbenogeografski in idejni prispevki}

Ta del Gamsovega znanstvenoraziskovalnega dela je javnosti manj znan, odraža pa izjemno širino njegove geografske misli in nemirnega duha, ki se je živahno odzival na aktualna družbenopolitična dogajanja doma in po svetu.

Že zgodaj se je spoprijel z agrarno geografijo (Gams 1957a), ki ji je v študijah o regionalnih razlikah preobrazbe kmetijstva v Alpah (Gams 1969a) in vrednosti vlažnotropskega pasu za kmetijstvo (Gams 1972c) vdihnil širše regionalne ter svetovne razsežnosti. Pomemben je njegov prispevek h geografskemu raziskovanju problematike hribovskih kmetij v osemdesetih letih prejšnjega stoletja, pri čemer je obdelal slovenjgraško Pohorje (Gams 1982b, 1983e in 1984a), že prej pa je skupaj z Medvedom raziskal preobrazbo hribovskega naselja Ojstrica nad Dravogradom (Medved in Gams 1968). V soavtorstvu (Gams, Lovrenčak in Ingolič 1971; Gams in Gabrovec 1999) ali sam (Gams 1987i in 1991n) je preučeval kmetijsko rabo tal na krasu in kraške agromelioracije, iz česar se je pod njegovim vodstvom razvila slovenska šola pokrajinske ekologije (Kunaver 2005, 9).

V svojem zgodnejšem ustvarjalnem obdobju ga je pritegnil razvoj turizma (Gams 1956a, 1959b, 1963a, $1963 \mathrm{c}$ in 1963e), spoprijel se je z geografijo prometa (Gams 1957c), v zrelem obdobju pa se je nekajkrat razpisal o stanju oziroma možnostih gospodarskega razvoja (Gams 1994b, 2001a in 2002b). V ta sklop spadata 
tudi oba energetsko obarvana prispevka (Gams 1957b; Pagon in Gams 1971). Tuja mu ni bila niti prebivalstvena tematika, s katero je odprl svoj veličastni avtorski opus (Gams 1952a, 1952b in 1952c). Demografskim študijam doma (Gams 1961b) in po svetu (Gams 1958b) so sledila razmišljanja o demografski ogroženosti Slovencev (Gams 1962a in 1972e), pripravil je tudi zapisa o prebivalstveni gostoti po naravnogeografskih pasovih Zemlje (Gams 1978b) in razpoložljivem življenjskem prostoru človeštva (1982d).V ta sklop sodijo tudi njegovi pogledi na pomanjkanje in lakoto v svetu (Gams 1988o). Nekaj posebnega je njegova primerjalna razprava med prebivalstvom Afganistana in zahodnega dela Balkanskega polotoka (2001b). Na podlagi izsledkov popisa prebivalstva leta 1991 je svoj učbenik Geografske značilnosti Slovenije dopolnil z aktualnimi družbenogeografskimi spremembami (Gams 1993b).

Gams je bil izvrsten opazovalec življenja v tujih deželah. Objavil je zapise o svojih videnjih Romunije (Gams 1967a), Bolgarije (Gams 1967e) in Sovjetske zveze (Gams 1975b). Predvsem v zrelejšem ustvarjalnem obdobju je pri predstavitvi posameznih dežel uporabil problemski pristop. Na ta način je geografom in širšemu bralstvu približal Kitajsko (1956d), Tunizijo (1968e), Pirenejski ali Iberski polotok (Gams 1979b), Japonsko (Gams 1980a), Skandinavijo (Gams 1980c), Malto (Gams 1986b) in Izrael (Gams 1990f).

Občasno je javnost seznanjal s svojimi pogledi na geografijo (Gams 1970d in 1977a; Gams s sod. 1981), njeno organiziranost (Gams 1970a in 1972f) in slovensko geografsko raziskovanje (Gams 1960c, 1983f, 1985h, 1986c in 1992i) ter razmejevanja med znanostjo in paraznanostjo (Zavrnik s sodelavci 1993). Zamislil si je in načrtoval nacionalni atlas, enega od osrednjih slovenskih geografskih raziskovalnih projektov, (Gams 1966b, 1967b in 1968a), ki je po dolgotrajnih prizadevanjih pod naslovom Geografski atlas Slovenije izšel šele leta 1998 (Fridl s sodelavci 1998). Že zgodaj se je zavedel tudi vloge in pomena občinskih atlasov (Gams 1981c), vendar so ti, predvsem zaradi pomanjkanja sredstev, prejkone ostali le dobra zamisel.

Vseskozi se je zanimal za šolsko geografijo in geografsko izobraževanje. Že na začetku kariere se je dotaknil problematike visokih šol in znanstvenih ustanov (Gams 1953 b). Pozneje je pogosto razmišljal, razpravljal in polemiziral o osnovnošolskem (Gams 1969b; Gams in Šircelj 1970; Gams 1993c), srednješolskem (Gams 1974a, 1975a, 1993c in Gams 2002d; Gams, Resnik Planinc in Saarinen 1993) in visokošolskem (Gams 1960b in 1991k) izobraževanju.

Deloval je tudi kot politični geograf. Svoja stališča je javno izpostavil ob upravnopolitični reorganizaciji osamosvojene Slovenije. Lotil se je tako ustanavljanja novih občin (Gams 1991b) kot še vedno neuspešnega vzpostavljanja pokrajin (Gams 1998b). Vseskozi so ga zanimala aktualna politična dogajanja v bližnji (Gams 1992b) in bolj oddaljeni okolici (Gams 1994i in 1994k), pri čemer se je zavzemal za boljši, varnejši jutri brez vojn in oboroženih spopadov. Seveda ga je zanimalo tudi slovensko zamejstvo. Te tematike sicer ni poglobljeno raziskoval, se je pa do aktualnih dogajanj občasno opredeljeval v časopisju (Gams 1972d, $1979 \mathrm{c}$ in 1995e).

\section{Leksikonski in enciklopedični prispevki}

Zaradi svoje široke razgledanosti in geografske širine je bil Ivan Gams vedno dobrodošel pri pripravi leksikonov in enciklopedij. Svoje tovrstno poslanstvo je začel s pisanjem gesel za četrto knjigo Krajevnega leksikona Slovenije (Savnik 1980), za katerega je ob opisih 34-tih naselij tedanje občine Slovenj Gradec prispeval še pregledne geografske opise vseh štirih koroških občin, zdajšnjih upravnih enot Dravograd, Radlje ob Dravi, Ravne na Koroškem in Slovenj Gradec. Za naselja občine Slovenj Gradec je pripravil opise tudi v najnovejši različici Krajevnega leksikona Slovenije (Orožen Adamič, Perko in Kladnik 1995; Orožen Adamič, Perko in Kladnik 1996).

S 15 gesli je sodeloval pri projektu Enciklopedija Jugoslavije, ki je bil v šestih knjigah pripravljen do vključno črke K, potem pa je z razpadom nekdanje skupne države leta 1991 zamrl. Njegova domena so bili opisi slovenskih dinarskih in gorskih pokrajin (Gams 1983b, 1985b, 1985e, 1988k, 1990d in 1990e), pripravil je celovita zapisa o reliefu Jugoslavije (Gams 1990c) in slovenskih Alpah (1983a) ter zapise o pogorju Dobrač v zamejstvu (Gams 1987g) in treh pomembnih slovenskih jezerih (Gams 1985a, 1985c in 1985d), pa tudi o dveh naseljih (Gams 1987h; Gams in Šašel 1985) ter enem najpomembnejših slovenskih geografov Svetozarju Ilešiču (Gams 19881).

Zelo se je izkazal pri osrednjem slovenskem enciklopedičnem projektu Enciklopedija Slovenije, ki je med letoma 1987 in 2002 izšel v 16. zvezkih. Zanj je samostojno ali v soavtorstvu prispeval 91 gesel, med 
njimi tudi nekaj ključnih (Gams 1988g, 1989c, 1989d, 1989e, 1989f, 1991f, 1995i, 1996e in 1996g; Gams in Petkovšek 1990; Gams s sod. 1996; Gabrovec, Gams in Hrvatin 1997).

Pomemben je njegov prispevek pri opisovanju slovenskih pokrajin (Gams 1987b, 1987d, 1988b, 1988č, 1988h, 1988i, 1990a, 1992d, 1992e, 1995j in 1997d; Gams, Ajdič in Ferenc 1987; Gams s sod. 1987; Gams in Ramovš 1990a in 1990b; Gams, Ramovš in Križnar 1990; Gams in Ževart 1993; Gams s sod. 1995). Sodeloval je pri pripravi gesel o slovenskih zgodovinskih pokrajinah (Gams s sod. 1989; Gams in Štrucl 1991; Gams in Marušič 1995; Gams in Ževart 1999b) ter kraških pojavov in krasoslovju (Gams 1991h, 1991i in 1991j; Gams in Šušteršič 1991). Napisal je tudi mnoga gesla o slovenskih in koroških gorah (Gams 1988j, 1989g, 1991d, 1992g, 1994c, 1994e, 1994f in 1998e; Gams, Čas in Wraber 1994; Gams in Linasi 1998; Gams, Wraber in Kunc 2000), jezerih (1987c, 1987e, 1988f, 1991c, 1992f, 1994g, 1995k, 1995h in 2000; Gams s sod. 1988), vodotokih (Gams 1996f; Gams s sod. 1993; Gams, Zupan in Povž 1994; Gams in Toman 1995), naseljih (Gams 1988c, 1994d, 1995f, 1997c, 1998c, 1998d in 1999b; Gams in Grafenauer 1992; Gams in Hozjan 1993; Gams in Linasi 1994; Gams in Stopar 1994; Gams in Ževart 1994 in 1999b; Gams, Mlinšek in Oder 1999) in občinah (Gams in Skoberne 1997a in 1997b).

Pripravil je osrednje geslo, ki opisuje Koroško, Kärnten (Gams 1991e), ter gesla o tamkajšnjih pokrajinah (Gams 1988a, 1992c, in 1995g; Gams in Linasi 1996). Kot izvrsten kronist je pripravil tudi zapise o srbskem geografu Jovanu Cvijiću (Gams 1988e) ter o slovenskih geografih Svetozarju Ilešiču (Gams 1990b), Andreju Kranjcu (Gams 1991g), Vitalu Manohinu (Gams 1992h) in Darku Radinji (Gams 1996d).

Ivan Gams je velik ljubitelj gora. To kažejo njegovi že omenjeni enciklopedični prispevki, morda pa še bolj več kot deset člankov v Planinskem vestniku, v katerih je z značilno osebnostno noto predstavil slovenske vzpetine od najvišjih gora Julijskih Alp do gričev Goričkega (Gams 1953c, 1954, 1955a, 1956c, 1960a, 1962d, 1966a, 1972i, 1977e in 1987a), pa tudi goro Midžor na meji med Srbijo in Bolgarijo (1988q). O sodobnem popotovanju od Litije do Čateža je poročal v Naših razgledih (Gams 1958a). Je eden od avtorjev planinskega vodnika Z Uršlje gore do Savinje (Gams 1958c in 1964d), pripravil pa je tudi regionalni opis naših gora v tržno uspešni fotomonografiji Slovenske gore (Gams 1982a). V sklop njegovih člankov o gorah lahko uvrstimo še zapis o višini najvišje gore sveta Mount Everesta (Gams 1955b). Kot navdušen fotograf je pripravil članek o fotografskem upodabljanju pokrajine (Gams 1959a). V svojem domačem okolju je objavil krajši zapis o spominih na otroštvo (Gams 1996i), kot človekoljub pa se je pokazal v zapisu o svojem odnosu do drugačnih (Gams 1995c).

Slika 4: Ziljska dolina z Dobračem v ospredju; Gams je bil pri pripravi enciklopedij zadolžen za prispevke o zamejski Koroški. Glej angleški del prispevka.

\section{Biografski prispevki}

Tudi če zanemarimo številna knjižna poročila, ki jih je redno objavljal predvsem v Geografskem vestniku, Ivan Gams zagotovo spada med naše najbolj prizadevne geografske biografe in kroniste. Tovrstne prispevke je bolj zavzeto pripravljal v drugi polovici svojega ustvarjalnega obdobja, ko si je že pridobil sloves zelo uglednega in objektivnega znanstvenika, katerega mnenje ima veliko težo. Zato ni presenetljivo, da je spremljal in ocenjeval znanstveno ustvarjalnost in pedagoško uspešnost vodilnih slovenskih geografov. Kar enajst prispevkov je namenil akademiku Svetozarju Ilešiču (Gams 1967c, 1977c, 1985f, 1985i, 1985l, 1985m, 1985n, 1986a, 1996c, 1999a in 2008). O drugem velikanu slovenske geografije Antonu Meliku je poročal le posthumno (Gams 1991m, 2005a in 2005c), podobno kot o naravoslovcu Ferdinandu Seidlu (Gams 1992a), predhodniku slovenske znanstvene regionalne geografije. Zelo se je angažiral tudi pri spremljanju življenjskih jubilejev in ob slovesu uglednega predstavnika medvojne generacije slovenskih geografov Valterja Bohinca (Gams 1968c, 1978a, 1984f in 1984g), predstavil pa je tudi delo in dosežke družbenega geografa, akademika Igorja Vrišerja (Gams 1990h in 1993a ter najmlajšega slovenskega geografskega akademika, krasoslovca Andreja Kranjca (Gams 1995d, 1996a in 2002a).

Ob življenjskih jubilejih in/ali smrti je predstavil tudi dosežke slovenskih geografov Franceta Planine (Gams 1971b), Vilka Finžgarja (1972a), Romana Savnika (Gams 1972b), Toneta Oblaka (Gams 1974c), Marjana Žagarja (Gams 1980d, 1981b in 1984c), Danila Furlana (Gams 1983c in 1983d), Ceneta Malovrha (Gams 1985j), Draga Mezeta (Gams 1986e, 1996b in 1996h), Darka Radinje (Gams 1987f, 1987l, 1997a in 1997b), Milana Šifrerja (Gams 1988n), Jurija Kunaverja (Gams 1993d in 2003), Petra Habiča (Gams 1994a) in Slave Rakovec (Gams 2002e), nekajkrat je pripravil tudi avtoportretne zapise o sebi in svojem delu 
(Gams 1988m in 1995a). Slovensko strokovno javnost je seznanil s smrtjo uglednih jugoslovanskih fizičnogeografskih kolegov Josipa Roglića (Gams 1987k, 1987m in 1987n) in Milislava Lutovca (Gams 1988p), pa tudi s slovesom eminentnih tujih fizičnih geografov, specializiranih v krasoslovje Jeana Corbela (Gams 1970b) in Herberta Lehmanna (Gams 1971c) ter geografa in geologa Juliusa Finka (Gams 1981a). Za Letopis Slovenske akademije znanosti in umetnosti je pripravil zapis o francoskem geomorfologu Jeanu Corbelu (Gams in Kranjc 2004), potem, ko je bil ta leta 2002 izvoljen za dopisnega člana SAZU.

V Geografskem vestniku, katerega sedemdesetletnico je ovekovečil z uvodnikom v 67. številki (Gams 1995l), se je poslovil tudi od akademskega kolege, geologa Ivana Rakovca (Gams 1986f), in jamarskega kolege Dušana Novaka (Gams 1998a), v češki jamarski reviji Speleo pa je predstavil enega od pionirjev sistematičnega raziskovanja in dokumentiranja kraškega podzemlja na Slovenskem ter enega od pobudnikov leta 1910 ustanovljenega Društva za raziskovanje jam v Ljubljani, na Moravskem rojenega Viljema Puticka (Gams 2002c), o katerem je že v petdesetih letih pripravil zapis v naši osrednji naravoslovni reviji Proteus (1956b).

\section{Uredniško delo}

Glede na velik avtorski prispevek je Gamsu zmanjkovalo časa za uredniško delo, verjetno pa je imel zanj manj smisla in do njega manjšo afiniteto kot za pisanje. Le redko je bil samostojni urednik, na primer publikacij Vodnik kongresne ekskurzije po dinarskem krasu iz leta 1965 in Karst processes and relevant landforms iz leta 1976 ter zbornika Naravne nesreče v Sloveniji kot naša ogroženost iz leta 1983. Pogosteje je bil v vlogi sourednika, na primer zbornika Dolenjska zemlja in ljudje iz leta 1962, Zbornika VI. kongresa geografov FLRJ $v$ LR Sloveniji, prav tako iz leta 1962, Jamarskega priročnika iz leta 1964, publikacij v angleščini Karst and man in Man's impact in Dinaric karst iz leta 1987 ter za geografsko stroko pomembne monografije Geografija Slovenije iz leta 1998. V letih 1983-1994 je bil sourednik znanstvene revije Geografski zbornik, kar 39let pa je bil član uredniškega odbora osrednje slovenske geografske znanstvene revije Geografski vestnik.

Ivan Gams je bil član številnih domačih in tujih znanstvenih teles (Kunaver 2005). Bil je predsednik Društva za raziskovanje jam Slovenije, med letoma 1968 in 1972 predsednik Geografskega društva Slovenije, nekaj časa pa tudi ljubljanske podružnice Geografskega društva Slovenije.

V letih 1983-1995 je bil predsednik znanstvenega sveta Geografskega inštituta Antona Melika ZRC SAZU. En mandat je bil tudi predstojnik Oddelka za geografijo Filozofske fakultete Univerze v Ljubljani.

Leta 1978 je bil izvoljen za dopisnega člana Slovenske akademije znanosti in umetnosti, od leta 1985 pa je njen redni član. Evropska akademija znanost in umetnosti s sedežem v Salzburgu ga je novembra 1993 izvolila za svojega rednega člana. Decembra istega leta je na predlog Oddelka za geografijo Filozofske fakultete dobil naziv zaslužni profesor. Je tudi častni občan občine Slovenj Gradec (Kunaver 2005).

\section{Sklep}

Kot je zapisal že Kunaver (2005), so izjemne osebnosti ena največjih dodanih vrednosti za stroko v nacionalnem okvirju, ker so doma dragocen vzgled, v tujini pa odmevajo. Tako mesto ima v slovenski geografiji Ivan Gams. Tega mu ne zagotavlja le obsežna bibliografija, ampak tudi širok pogled in zanimanje za najraznovrstnejše probleme v geografiji in aktualnem družbenem dogajanju. Med njegovimi najbolj izstopajočimi lastnostmi kot znanstvenika, raziskovalca in pedagoga so nekonformizem, pronicljivost, originalnost in mnogovrstnost geografske misli, utiranje novih raziskovalnih poti in prijemov, ter odkrivanje problemov, ki se jih doma pred njim navadno ni še nihče niti dotaknil. Temu lahko dodamo njegovo koroško trmo, nepopustljivost in neuklonljivost, s katerimi mu je uspelo hoditi po lastni poti, ne da bi se pri tem kakorkoli opiral na vladajoče kroge in izkoriščal ugodnosti »ustrezne« družbenopolitične pripadnosti.

Slika 5: Ivan Gams devoted several articles to Uršlja gora, also Plešivec, with its characteristic broad peak.

Glej angleški del prispevka.

\section{Literatura}

Glej angleški del prispevka. 